\title{
SUFOCO NAS ALTURAS \\ SOBRE PÁRAMO, DE GUIMARÃES ROSA ${ }^{1}$ \\ APRIETO EN LAS ALTURAS \\ SOBRE PÁRAMO, DE GUIMARÃES ROSA \\ SUFFOCATION AMONG THE HEIGHTS \\ ON "PÁRAMO" BY GUIMARÃES ROSA

\author{
LE MAL DES HAUTEURS \\ DANS PÁRAMO, DE GUIMARÃES ROSA
}

高空窒息 : 巴西作家吉马良斯·罗沙描述的恐高症

DOI: 10.5533/1984-2503-20135201

Gisálio Cerqueira Filho

\section{RESUMO}

O trabalho propõe uma interpretação sobre o conto "Páramo", do escritor brasileiro João Guimarães Rosa. Ele foi publicado post-mortem, sendo a primeira edição em 1969. Nele, anos após a experiência vivida na Alemanha, o autor conduzirá o leitor ao coração da recordação traumática: um encontro com a morte. Sim, um "encontro com a morte. Não a morte final - equestre, ceifeira, ossosa, tão atardalhadora, mas a outra, aquela". A morte aqui veste o semblante do sofrimento psíquico (pathos) intensamente vivenciado no soroche, o mal das alturas, em função do ar rarefeito naquelas altitudes, mas também na depressão profunda experimentada a partir daquele período de autoritarismo vivo (ethos) da Alemanha em guerra, expresso em números genocidas. A abordagem propõe um entrelaçamento entre história, cultura política e método clínico.

Palavras-chave: Teoria política, Literatura, Guimarães Rosa, Psicanálise, Método clínico.

\footnotetext{
${ }^{1}$ Rosa, João Guimarães (2001). "Páramo", In Estas Estórias, Rio de Janeiro: Nova Fronteira, 2001, p. 261290. Esta edição é referência para as citações. A primeira edição data de 1969, publicada postumamente, em volume organizado por Paulo Rónai e Vilma Guimarães Rosa.

${ }^{2}$ Gisálio Cerqueira Filho, sociólogo e cientista político. Doutor em Ciência Política (USP), é Professor Titular de Teoria Política na Universidade Federal Fluminense (UFF), Niterói, Brasil. Pesquisador sênior do Laboratório Cidade e Poder (UFF), membro da Associação Universitária de Pesquisa em Psicopatologia Fundamental (AUPPF), da Associação Nacional de História (ANPUH-Brasil), da Associação Brasileira de Ciência Política (ABCP) e do Research Committee on Sociology of Law (RCSL). Editor de Passagens. Revista Internacional de História Política e Cultura Jurídica Autor de vasta obra no Brasil e no exterior (Américas, Europa, Oriente). E-mail:gisalio@superig.com.br
} 


\section{RESUMEN}

El trabajo propone una interpretación sobre el cuento "Páramo", del escritor brasileño João Guimarães Rosa. Él fue publicado post-mortem, la primera edición es de 1969. En él, años después de la experiencia vivida en Alemania, el autor conducirá el lector al corazón de la recordación traumática: un encuentro con la muerte. Sí, un "encuentro con la muerte. No la muerte final - ecuestre, segadera, huesosa, tan perturbadora, sino la otra, aquella". La muerte aquí viste el semblante del sufrimiento psíquico (pathos) intensamente vivenciado en el soroche, el mal de las alturas, en función del aire rarefacto en aquellas altitudes, pero también en la depresión profunda experimentada a partir de aquel periodo de autoritarismo vivo (ethos) de la Alemania en guerra, expreso en números genocidas. El abordaje propone un entrelazamiento entre historia, cultura política y método clínico.

Palabras clave: Teoría Política, Literatura, Guimarães Rosa, Psicoanálisis, Método Clínico.

\section{ABSTRACT}

This article proposes an interpretation of the tale entitled "Páramo"3 by the Brazilian writer João Guimarães Rosa. The tale was published post mortem, with the first edition released in 1969. Years after his experience in Germany, the author leads the reader to the heart of a traumatic memory: an encounter with death. Yes, an "encounter with death. Not final death - equestrian, Grim Reaper, skinny and so unsettling, but the other one, that one". Death in the tale appears as psychological suffering (pathos) intensely experienced through soroche - altitude sickness - due to the thin air at high altitudes, but also through the deep depression experienced upon that period of thriving authoritarianism (ethos) in wartime Germany, expressed in countless genocidal killings. The approach proposes an intertwining of history, political culture and the clinical method.

Key Words: Political Theory, Literature, Guimarães Rosa, Psychoanalysis, the Clinical Method.

\footnotetext{
${ }^{3}$ Term in Portuguese and Spanish used to refer to bleak uplands. It is also sometimes used more narrowly to refer to the northern Andes of South America and adjacent southern Central America, and in Portuguese figuratively refers to the heavens and the sense of a summit or highest point.
} 


\section{RÉSUMÉ}

Ce travail propose une interprétation de la nouvelle Páramo, de l'écrivain brésilien João Guimarães Rosa, publiée post-mortem pour la première fois en 1969. Dans ce récit, des années après son expérience vécue en Allemagne, l'auteur conduit le lecteur au cœur du souvenir traumatique, à savoir une rencontre avec la mort. « Une rencontre avec la mort. Non pas la mort finale - équestre, faucheuse, osseuse, si déconcertante, mais l'autre, celle-là. » La mort revêt ici un semblant de souffrance psychique (pathos) intensément vécue comme un soroche, le mal des hauteurs dû à la raréfaction de l'oxygène en altitude, mais aussi comme une dépression profonde issue de la période d'autoritarisme concret (ethos) et de génocide de l'Allemagne en guerre. Notre approche propose de croiser histoire, culture politique et méthode clinique.

Mots-clés: Théorie politique, Littérature, Guimarães Rosa, Psychanalyse, Méthode clinique.

\section{提要}

本论文尝试对巴西作家若昂·吉马良斯・罗沙(João Guimarães Rosa)

的短篇小说“恐高症” 进行解读。作品于作者去世之后, 在1969年初次发表。在小说里面, 作者根据在二战时期的德国生活多年的经验, 把带读者带到一个与死亡相遇的精神临界点。 “与死亡面对面。不是死亡一

肉体, 大脑, 躯干的缓慢死亡, 而是另外一种”。在这部作品里, 死亡就像一种精神病态 (pat hos)类似于恐高症的状况soroche,

高空缺氧的窒息感觉，同时加上生活在高压统治之下的战争时期德国的极度忧郁状态 (ethos),

这种忧郁可以从大量的屠杀死亡人数得到旁证。论文试图结合历史, 政治文化和临床心理分 析疗法等角度综合解读这部小说。

关键词 : 政治学理论, 文学, 吉马良斯・罗沙, 心理分析, 临床疗法.

Para Lene, sempre juntos, porque bem separados.

[...] conhecia o sáurio, lagartixa que quando está velha e ficam cegos os seus olhos, entra num buraco que dá para o Oriente e ao sair o sol, olha para ele, se esforça para ver e recobra a vista ${ }^{4}$.

\footnotetext{
${ }^{4}$ Carpentier, Alejo (1987). A harpa e a sombra, Rio de Janeiro: Bertrand do Brasil.
} 
Estamos entre 1942 e 1944. Joãozito, como é conhecido João Guimarães Rosa (1908-1967), está a sentir "os pés frios do mundo", pois aceitara a nomeação como segundo secretário da Embaixada do Brasil em Bogotá, Colômbia. Lá produzirá uma joia da literatura universal com forte inscrição latino-americana. Nos páramos da Cordillera, elevados e nevados pontos a mais de 2600 metros de altitude, "en la cárcel de los Andes"6, evocará ficcionalmente a terrível experiência vivida no período em que fora consul adjunto em Hamburgo, Alemanha, entre 1938 e 1942. No conto, intitulado "Páramo" vai exorcizar a experiência opressiva de pathos duplamente inscrito em BadenBaden onde ficou confinado por cem longos dias depois de ser convocado à Berlim com outros diplomatas do Consulado em meados de 1942 e ter que aguardar o momento em que seriam trocados por alemães, detidos no Brasil, que enfim declarara guerra aos países do Eixo em agosto de 1942. Como cônsul adjunto em Hamburgo, Guimarães Rosa resistiu ao nazismo e ajudou de modo discreto, mas decisivo, muitos judeus perseguidos.

Em 1934, Guimarães Rosa fizera concurso para o Itamaraty. Seu primeiro posto foi na Alemanha, onde conheceu Aracy Moebius de Carvalho, sua segunda esposa, e a quem chamava de Ara. Aracy, do interior do Paraná, falava vários idiomas e fora morar com uma tia na Alemanha. Acabou por ser contratada pelo consulado brasileiro em Hamburgo. Em 1938 passara a vigorar a Circular Secreta 1.127 que restringia a entrada de judeus no Brasil.

Minha mãe resolveu ignorar a Circular, que proibia vistos a judeus, e por risco e conta dela continuou a preparar os processos à revelia das ordens superiores no consulado. Como ela despachava outras coisas com o cônsul-geral, no meio dos papéis enfiava os vistos. A iniciativa, embora contasse com o apoio discreto de João Guimaraes Rosa, partiu dela, pois como cônsul adjunto Guimarães Rosa não assinava os vistos. Mas sabia o que minha mãe estava fazendo e a apoiava?.

Em Hamburgo, Guimarães Rosa e Aracy já estavam separados dos seus respectivos cônjuges de primeiras núpcias. Depois da guerra ambos se casaram por procuração no México e logo a seguir ocorreu a nomeação de Guimarães Rosa para Bogotá, Colômbia. Desde 1946 o autor já vinha se dedicando cada vez mais à literatura. Em 1936 havia publicado "Magma". Coincidindo com o fim da guerra, lançara "Sagarana" (1946). Logo virão "Com o vaqueiro Mariano" (1947), "Corpo de Baile" (1956) e "Grande

\footnotetext{
${ }^{5}$ Rosa, João Guimarães (2001a). "Páramo". Op. cit. p. 263.

${ }^{6}$ Rosa, João Guimarães (2001a). "Páramo". Op. cit., p. 264.

7 Ver relato de Eduardo Tess, filho do primeiro casamento de Aracy in Decol, René Daniel (2006). "Uma certa Aracy, um certo João". In Revista GOL - Linhas Aéreas, Secção "Gente”, p.72.
} 
Sertão: Veredas" (1956) para ficarmos com o limite do final de década de cinquenta do século $X X$.

Na literatura roseana desponta uma "osmose entre literatura e geografia e, como prolongação, uma osmose entre mitologia e moral, entre oralidade e escrita, entre passado e presente" significar mais uma troca recíproca entre estética, ética e Natureza, embora a metáfora seja reveladora de um certo naturalismo de cunho biologista com que o social, talvez, possa estar sendo pensado.

O conto "Páramo", todavia, foi publicado post-mortem, sendo a primeira edição em 1969. Nele, anos após a experiência vivida na Alemanha, o autor conduzirá o leitor ao coração da recordação traumática: um encontro com a morte ${ }^{9}$. Sim, um “... encontro com a morte. Não a morte final - equestre, ceifeira, ossosa, tão atardalhadora, mas a outra, 'aquela"10.

A morte aqui veste o semblante do sofrimento psíquico (pathos) intensamente vivenciado no soroche ${ }^{11}$, o mal das alturas, em função do ar rarefeito naquelas altitudes, mas também a depressão profunda (deep pression) ${ }^{12}$ experimentada a partir daquele período de autoritarismo vivo (ethos) da Alemanha em guerra ${ }^{13}$, expresso em números genocidas.

Neste trabalho a escritura e a trama dos personagens serão tomadas por nós como fontes de observação em relação aos conceitos de ethos e pathos, referidos à vivência do protagonista central.

Recorde-se que ainda hoje "Páramo", a um só tempo história e ficção, é um conto relativamente desconhecido. Por isso mesmo recomendamos, a despeito de qualquer interpretação nossa ou de outrem, a leitura atenta do referido conto. Que o leitor deixe-se levar pelo alumbramento "desse caminho rápido demais que é o sofrimento. Tenhamos pena, irmãos, uns dos outros, reze-se o salmo Miserere. Todavia, ao remate da prova,

\footnotetext{
8 Torres Fierro, Danubio (2012). "Romance entre o arcaico e o moderno". In O Estado de São Paulo, Suplemento Sabático, 18/08/2012, p.6-7.

${ }^{9}$ Cerqueira Filho, Gisálio (2011). "Amor \& Morte em Arthur Schnitzler". In Passagens - Revista Internacional de História Política e Cultura Jurídica, Rio de Janeiro, v. 3 n.1, jan./abr., p. 142 -164.

${ }^{10}$ Rosa, João Guimarães (2001a). "Páramo". Op. Cit, p. 264.

11 Santiago, Silviano (2012b). "Soroche o mal das alturas", artigo instigante publicado in O Estado de São Paulo, Suplemento Sabático, 21 jun., p.2.

12 Cerqueira Filho, Gisálio (2006). "Dor e Medo na clínica em extensão". In Psicologia Clínica, Rio de Janeiro: PUC-RIO, v. 18, n.1, p. 123-135.

${ }^{13}$ Cerqueira Filho, Gisálio (2005). Autoritarismo Afetivo: a Prússia como sentimento. São Paulo: Escuta.
} 
segue-se a maior alegria"14. O pathos já se revela aqui na sua inteireza como sofrimento, mas também como fruição de gozo e, quiçá, como via para o registro do estético.

O alumbramento que, sob a forma de ansiedade funérea, absorve o personagem não era estranho a Guimarães Rosa. Em "Meu tio o lauaretê", o autor brasileiro já narrara a estória de um mestiço de índia com branco e seu destino exemplar: "agregado de fazendeiro que o envia para desonçar sozinho nos confins do sertão, vai gradativamente rejeitando o civilizado e se reconhecendo no animal. Acaba preferindo onças a homens, acaba virando onça e matando homens". ${ }^{15}$ O natural o toma por inteiro ${ }^{16}$.

Ethos é o construto sociológico para a natureza social do humano, referido tanto à comunidade quanto à sociedade. No caso concreto diz respeito aos aspectos característicos daqueles que vivem no sertão, mas também os transcendem. Aspectos que falam dos costumes, da cultura, da ideologia, do simbólico, enfim. Não há dúvida que fala à identidade social. De origem grega, a expressão ethos também se refere a uma ética; ética do ângulo dos valores, hábitos, costumes, leis. Para Max Weber (1864-1920), por exemplo, o ethos burguês deve ser tratado como falta ou dever e, no caso, relacionado à ética protestante capitalista. Já em Georg Simmel (1858-1918), as instituições sociais e o território tem destaque na formação do ethos de uma sociedade. No ethos temos sempre presente um caráter acentuadamente normativo. Pathos é construto psicológico para a natureza psíquica do humano. Representa o sofrimento, a experiência afetiva, as emoções. O protagonista de "Páramo" assume o sofrer como uma desdita inescapável, condenação inapelável, embora de razão desconhecida. "Quebrantado e sozinho, tornado todo vulnerável, sem poder recorrer a apoio algum visível, um se vê compelido a esse caminho rápido demais que é o sofrimento"17. Expressão também de origem grega, pathos fala ao imaginário, aos sentimentos, às emoções inconscientes, aos afetos, às paixões, que marcam e diferenciam homens e mulheres do sertão enquanto metáfora para o Brasil profundo. A expressão pathos é evocativa de um sofrimento implícito no sentir a dor presente no corpo e na imaginação. Pretendemos aqui demonstrar como articular ethos e pathos enquanto construtos específicos referidos ao conto "Páramo" com base no método clínico. A Psicopatologia

\footnotetext{
${ }^{14}$ Rosa, João Guimarães (2001a). "Páramo". Op. Cit, p. 262.

15 Cf. Campos, Haroldo de (1970). "A linguagem do lauretê". In Metalinguagem, 2. ed., Petrópolis, RJ: Vozes, 1970, p. 47-53.

${ }^{16}$ Almeida, Leonardo Vieira de (2011). Veredas do Grande Conto: a descoberta do sertão em Guimarães Rosa, Rio de Janeiro: Ed. PUC-RIO \& Uapê, p. 99.

${ }^{17}$ Rosa, João Guimarães (2001a). "Páramo". Op. Cit., p. 262.
} 
Fundamental, quando propõe que o pathos vem de fora e de longe, supõe uma íntima articulação com o ethos. Isso é particularmente evidente, por exemplo, nos trabalhos de Freud sobre a neurose de guerra ou neurose traumática. Certamente que as noções de observação e natureza que regem o método clínico incluem ambos os conceitos.

Podemos dizer que o humano é portador de subjetividade e apresenta um aparelho psíquico que incluí uma dimensão inconsciente. A dinâmica desse fenômeno é regida pelo pathos (sofrimento, paixão, passividade), pelo afeto. Entretanto, afeto não deve ser confundido com emoção simplesmente. O afeto contém a emoção, mas não se reduz a ela. O afeto é uma força, é uma paixão intensamente excessiva. Podemos dizer com Manoel Berlinck que o pathos é um "afetão", ou seja, aquilo que atinge e modifica o sujeito $^{18}$. Nem toda emoção provoca essa mudança. Dessa forma, pathos designa a experiência daquilo que é vivido. É um estado transitório. Podemos então dizer que a Psicopatologia Fundamental é um discurso sobre o afeto, uma paixão que é vivida pela experiência ${ }^{19}$.

Em "Neurose de Transferência: uma síntese", ensaio de Sigmund Freud (18561939), escrito entre 1914 e 1915, mas descoberto após sua morte e publicado em 1987, temos a elaboração de uma construção teórica, fundada tanto num mito quanto numa epopeia de natureza poética, para as origens da psicopatologia psicanalítica numa perspectiva filogenética, que coincide com a da subjetividade humana. Freud apresenta sua concepção de que o psiquismo humano é psicopatológico a partir da catástrofe glacial. Segundo ele, a história do desenvolvimento da energia sexual, denominada libido, repete uma parte do desenvolvimento filogenético bem mais antiga do que o do eu. Especula então que o que hoje são neuroses foram fases do desenvolvimento da humanidade. Assim, a era glacial ameaçou a sobrevivência da espécie que encontrou na neurose de transferência formas criativa de proteger-se dessa ameaça e que foram constituindo o psiquismo humano. Para Freud, pelo menos nesse importante texto, não há como separar corpo e psique, sobretudo não há como distinguir subjetividade e psicopatologia. Também não há como supor que as manifestações psicopatológicas não sejam também somáticas ou se distingam da subjetividade. Para Freud, histeria, perversão, obsessão, etc. são modos de subjetivação, ou melhor, são subjetividades, pois o sujeito se constitui somente por essa via. É por isso que é possível falar de uma

\footnotetext{
${ }^{18}$ Berlinck, Manoel Tosta (Org) (2005). Obsessiva Neurose, São Paulo: Escuta.

${ }^{19}$ Rodrigues, Márcia Barros Ferreira (2008). Ethos e Pathos: Violência e Poder em Casa Grande \& Senzala, de Gilberto Freyre. Projeto de Pós-doc. UFF, Supervisor Prof. Gisálio Cerqueira Filho, Niterói.
} 
psicopatologia fundamental, pois o que não institui a subjetividade pela via psicopatológica produz o extermínio. Ou seja, a nossa subjetividade se construiu de alguma forma apoiada no medo ${ }^{20}$.

Desde a ótica do Eu, a subjetividade freudiana remeteria, imediatamente, à psicopatologia que se denomina de fundamental em distinção a outra, psiquiátrica, que se denomina psicopatologia geral. Assim, na perspectiva freudiana, a subjetividade só se manifesta pela via psicopatológica, afastando-se do racionalismo cartesiano. De qualquer forma, quanto mais primitiva a paixão (pathos) mais o paciente se encontra a mercê de uma ação que se origina no Outro ${ }^{21}$.

Gostaríamos de trabalhar a articulação entre esses dois aspectos (pathos e ethos) referidos ao conto "Páramo" como metáfora para a circunstância vivida na Alemanha por João Guimarães Rosa e logo quando da chegada a Bogotá, onde vai desempenhar as funções diplomáticas de segundo secretário junto à Embaixada do Brasil na Colômbia. Não há dúvida que se trata de uma compreensão mais complexa da temporalidade histórica com inspiração numa visão diacrônica (sugerida por Walter Benjamin) acentuando-se "a ideia de sobrevivência (Nachleben) de tópicos e imagens do passado por uma relação sensível empática ou patética (Pathosfornel) como projeto realizado por Aby Warburg em "O nascimento de Vênus e A Primavera de Sandro Botticelli", publicado em 1891"22. Aby Warburg realiza um projeto complexo, com imaginação e refinamento. Seu método se aproxima [...]

do trabalho de detetive relacionado à história da cuttura nos detalhes e entrelaçamento dos tempos, jogos de diferenças, retomos, anacronismos, que segue algo parecido a um traço incessante, mas inconstante do ir e vir das ondas sobre as margens do tempo. Como dizia de Deus, o tempo também se oculta nos detalhes. Há que se insistir na sua busca. Embora nomeado com reverência e seja muito nomeado, Warburg não é tão lido. Sua escritura é tão deslumbrante quanto labiríntica. De suas publicações já se disse que cada página corresponde a quinhentas manuscritas, milhares de notas e centenas de livros lidos ${ }^{23}$.

\footnotetext{
${ }^{20}$ Veja-se o instigante ensaio de Ginzburg, Carlo (2006). Medo, Reverência e Terror: Reler Hobbes Hoje, tradução de Luiz Fernando Franco, Niterói, Laboratório Cidade e Poder (in European University Institute, Max Weber Lecture Series - MWP - 2008/ 05, com o título Fear, Reverence Terror: reading Hobbes today, (ISSN 1830 7036), Badia Fiesolana, Italy.

${ }_{21}$ Berlinck, Manoel Tosta (2010). O Método Clínico: projeto temático de pesquisa, São Paulo, CNPq. Mimeo 22 Schollhammer, Karl Erich (2012). "A sobrevivência de Aby Warburg". In O Globo, Caderno Prosa e Verso, Rio de Janeiro, 08 set., p. 5. Ver Warburg, Aby (2012). O nascimento de Vênus e a A Primavera de Sandro Botticelli (1891), tradução para o português de A. Mourão, Lisboa: KKYM.

${ }^{23}$ Reguera, Isidoro (2010). "Abby Warburg: Inventor del museo virtual". In El Pais, Babelia, Madrid, n. 962, 01 maio. Ver ainda Didi-Huberman, Georges (2009). La imagen superwiente, Madrid: Editorial Abada.
} 
Por fim, se a metodologia a ser empregada é própria do método clínico, tal como é concebido pela Psicopatologia Fundamental, não é menos verdade que esta se relaciona com o que Carlo Ginzburg (Premio Balzan, 2010, Itália) designou como metodologia indiciária, ou seja, aquela que opera a partir da observação de sinais, pistas, indícios; algumas vezes a escapar do olhar e da escuta do mais atento analista. Não há dúvida que, em muitas circunstâncias devemos assinalar que os limites e o rigor (flexível como sugere Ginzburg) do paradigma indiciário saltam à vista. Mas Ginzburg não acredita em qualquer interpretação que se apresente a respeito de uma pintura ou um texto; acrescentaríamos, a um caso clínico qualquer. $E$ frequentemente analisa os limites da prova nas suas conjecturas e insights interpretativos. Todavia, "é justamente na relação entre conjecturas e refutações através de experimentos sucessivos que se vislumbram as provas de hipóteses arriscadas, sem as quais o conhecimento se empobrece". ${ }^{24}$ Leve-se em conta também, quando da interpretação do discurso do Outro, o quanto esse Outro aceita a referida interpretação. Muitas vezes, a não aceitação da interpretação aparece como resistência, é verdade. Mas sempre e quando esse Outro não tiver uma alternativa à interpretação proposta, estaremos diante do enigma de termos... nenhuma interpretação. E aqui incidem os mais agudos desafios para inovação quando dos estudos sobre o humano.

Sabemos com Martin Heidegger, e como acentuou Jacques Lacan, que a construção própria da observação é um longo caminho em direção à palavra e à linguagem ${ }^{25}$.

Ainda com Warburg e a pintura "O nascimento de Vênus" no pensamento europeu podemos resumir nosso intento: a transformação do pathos fúnebre em pathos erótico.

Pois o conto "Páramo" trata do pesadelo da morte. Guimarães Rosa trabalhava neste conto (finalizando-o, quem sabe?) quando veio o seu próprio fim por enfarte súbito em 1967, três dias após a posse na Academia Brasileira de Letras ( $A B L)$. Ele, que postergara por quatro anos a sua efetivação como acadêmico. O discurso de posse denominava-se "O Verbo e o logos". Lá constava a frase "A gente morre é para provar que viveu". Um dia após o enterro Carlos Drummond de Andrade escreveu o poema "Um chamado João", e conclui: "Ficamos sem saber o que era João/ e se João existiu/ de se

\footnotetext{
${ }^{24}$ Sobral, Luis Felipe (2012). "No rastro de Piero". In Revista Brasileira de Ciências Sociais - RBCS, São Paulo, v. 27 n. 79 , p. 220.

${ }^{25}$ Heidegger, Martin (2003). A caminho da linguagem, Petrópolis, RJ: Vozes. Berlinck, Manoel Tosta (2010). Op. Cit.
} 
pegar". Ficamos nós com a brincadeira do "o que é o que é...?" e a pergunta síntese que propomos: O que é/ o que é/ não se pega/ e tem pegada?

Responda você, caro leitor.

Afinal, e para passar o tempo, quando confinado naquela Baden-Baden opressiva, Joãozito adorava participar dessa brincadeira de perguntas e respostas.

Agora, num movimento oposto, e já em Bogotá, Colômbia, o autor brasileiro pode evocar as agruras e sofrimentos de um personagem moço e estrangeiro nas alturas da Cordilheira Andina, a vivenciar a "morte em vida" nos termos de uma angústia imorredoura de um estrangeirado (um brasileiro em Bogotá!?). Daí porque nos parece oportuno recepcionar, tanto o conto "Páramo" no original português quanto na sua correspondente tradução para o espanhol. Para não falar na linguagem das etnias dizimadas, a morte naquele alto dos Andes há de ser pensada minimamente em português brasileiro com travo de português camoniano (Camões), enriquecida dos neologismos da oralidade tomados como palavras novas, e - finalmente - em castelhano. A tradução para esse idioma foi realizada por Bairon Oswaldo Vélez Escallon e só em 2011, numa conexão da integração e solidariedade sul-americanas (im)postas pelo tempo presente. Buscamos os sinais do que afinal se fala e se faz naqueles contrafortes da Cordilheira, que funcionam como um cárcere. Marcas, pistas, indícios são "sintomas de tudo o que é recalcado na construção dos relatos explicativos que visam adjudicar o valor do literário, que o imaginário se incorpora à existência como o que garante a sua falta de acabamento, isto é, a sua sobrevivência" ${ }^{\prime 2}$. Não é surpresa que naquelas alturas neblinosas ressurjam angústia e sofrimento vividos em Baden-Baden, Alemanha. A expressão germânica é signo do sintoma repetido e, no duplo, replicado. O duplo a que nos referimos está presente na caminhada em que o protagonista imagina algo em si próprio de uma morte imperfeita, mas projetada a partir de si e que se volta contra si como pesado fardo a carregar. Este duplo está assim representado sucessivamente: trata-se do "homem com a semelhança do cadáver". Ele é nomeado ainda como "homem com o aspecto de cadáver", "homem com fluidos de cadáver", "homem com presença de cadáver", "homem frio como um cadáver", "homem com ar de cadáver", "homem com alguma coisa de cadáver". Todas essas expressões vão se sucedendo ao longo do conto como referência, numa circunstância psíquica especial (psicótica?), ao seu duplo

\footnotetext{
${ }^{26}$ Vélez Escallon, Bairon Oswaldo (2012). "Intrusões: Guimarães Rosa-Bogotá: notas para uma tradução de Páramo". In Revista Tussaji, v. 1, p.68.
} 
enquanto réplica que emerge como pulsão de morte, a um só tempo, fatídica e revigorante. Tudo consoante a frase pronunciada na posse na $\mathrm{ABL}$ : "A gente morre é para provar que viveu". Há aqui uma conexão entre morte e ressurreição. Pois, no conto, um médico judeu intervém e salva o protagonista de uma morte iminente e triste Assim define-se o renascido: "cada criatura é um rascunho a ser retocado sem cessar, até a hora da liberação pelo arcano" 27.

Após dizer que havia algo de premonitório naquela cidade nas alturas a que acabara de chegar o personagem não esconde "que se sentia ofuscado pelas bulhas da vida, de engano a engano, entre passado e futuro - trevas e névoas - e o mundo maquinal'28. Embaralhavam-se passado, presente e futuro; trevas (inferno), névoas (o paraíso, tendo o céu como metáfora); o presente referido aqui ao mundo maquinal, quando Guimarães Rosa diz do "sono rancoroso dos minérios", famoso verso do poema "A Máquina do Mundo", de Carlos Drummond de Andrade. E mais ainda. Para Silviano Santiago, o verso inesperado aponta para uma revisão do conto realizada por Guimarães Rosa em 1948, portanto na segunda viagem que o autor e diplomata fez a Bogotá; desta vez acompanhando o Ministro João Neves da Fontoura para participar da IX Conferência Panamericana. Vejamos comparativamente o texto de Rosa e o poema de Drummond: Ali em antros absconsos, na dureza da pedra, no peso de orgulho da terra, estarão situados os infernos, no sono rancoroso dos minérios ${ }^{29}$ E logo o fragmento do poema: [...] tudo que define o ser terrestre/ ou se prolonga até nos animais/ e chega às plantas para se embeber/ no sono rancoroso dos minérios,/ dá volta ao mundo e torna a se engolfar, /na estranha ordem geométrica de tudo [...]. ${ }^{30}$

Nessa ocasião é que ocorre o famoso Bogotazo, uma série de levantes de rua em função do assassinato do candidato liberal à presidência da República Jorge Eliécer Gaitán durante o governo de Mariano Ospina Pérez. Gaitán estava agendado para se encontrar a tarde com os líderes cubanos Fidel Castro e Rafael del Pino para falar sobre o Congresso Latino-americano da Juventude. Lá eles esperavam Gaitán para fazer o último discurso. Gaitán deixou seu gabinete, e, fora do prédio, foi baleado duas vezes na cabeça e depois no peito, com uma pistola às 13:15 horas, tendo sido levado para um hospital local onde não resistiu e veio a falecer alguns minutos depois. Em função do evento pan-

\footnotetext{
${ }^{27}$ Ver Santiago, Silviano (2012b). Op. Cit.

${ }^{28}$ Rosa, João Guimarães (2001a). "Páramo". Op. Cit., p 264.

${ }^{29}$ Ibidem, p 265.

${ }^{30}$ Andrade, Carlos Drummond de (2002). "A Máquina do Mundo". In Folha de São Paulo, Mais!, 27 out, p. 20.
} 
americano, não só muitos líderes políticos estavam presentes, assim como diplomatas, jornalistas e correspondentes de imprensa. Entre eles estava Antonio Callado, que era membro da Delegação brasileira. Surpreso por não ter visto Guimarães Rosa durante o Bogotazo, Callado o interroga na primeira oportunidade querendo saber se não havia visto o levante nas ruas. Tratara-se de uma visão terrível. Chega a comparar as tantas mortes com a história de Augusto Matraga. Mas Guimarães Rosa não se abala e responde-Ihe: "Ora Callado, o que eu tenho que escrever está tudo na minha cabeça. Não preciso ver coisa alguma... Já fiz um livro e estou fazendo outros". Insatisfeito, Callado pergunta por onde andara; o que fizera. E a resposta vem de pronto: "Eu reli Proust"31.

A resposta é estupenda. É Marcel Proust que nos conduz, na literatura, pelos caminhos da subjetivação gozoza: ah! o sabor da madeleine.

Em certa oposição complementar à saga proustiana [...]

[...] se Freud interpreta as associações de ideias pela via do que escondem em seu próprio interior; Proust, igualmente, mostra como uma pequena palavra revela elementos escondidos na psicologia do personagem. O mesmo, no caso, de lembranças involuntárias. A lembrança da madeleine molhada numa taça de chá, que remete a um momento análogo da adolescência do herói, que teria também mergulhado uma madeleine no chá, traz a imagem de Combray. Como escreve Proust: Combray saiu da minha taça de chá. Esse é um fenômeno de associação e exploração do inconsciente por Proust ${ }^{32}$.

Todavia, apenas três dias após chegar à cidade, já estava vivenciando uma experiência radical de des-subjetivação: nas alturas, mareado, mas não pelo mar; sim, pela altitude muito acima do nível do mar... ; o frio insofrível, uma névoa difusa e sombria sempre presente, uma aflição sem par. Não era dali, não tinha um nome, um amor, não tinha casa. Indagava-se: teria, um corpo ${ }^{33}$ Não podia "atinar a ver o transiente rigor que me aguardava, por meu clã-destino, na mal-entendida viagem, in-via, e que era a absoluta cruz, a vida concluída, para além de toda conversação humana, o regresso ao amargo"34. É verdade que passara não por uma aduana comum, mas pela "alfândega das almas" ${ }^{35}$ Vivia por antecipação o que, séculos antes, Hamlet descreveu como "o pavor de algo após a morte/ a terra desconhecida de cujas fronteiras/ viajante nenhum retorna".

\footnotetext{
${ }^{31}$ Ver Costa, Ana Luiza Martins (2006) . "Memória seletiva - Veredas de Viator". In Cadernos de Literatura Brasileira, Rio de Janeiro: Instituto Moreira Salles, n. 20/21, p. 25

32 Tadié, Jean-Yves (2012). Le lac inconnu - entre Proust e Freud, Paris: Gallimard.

${ }^{33}$ Rosa, João Guimarães (2001a). "Páramo". Op. Cit., p. 263.

34 Ibidem, p. 263.

${ }^{35}$ Ibidem, p. 266
} 
Todavia, isso não era tudo. Ainda, não! Faltava o derradeiro tiro de misericórdia que viria sob a forma de um "golpe de-Job" ${ }^{\text {"3 }}$. O famoso golpe de box denominado job vem aqui involucrado foneticamente no sofrimento bíblico de Job. Então muito popular na América Latina, a luta de box aproxima num só golpe o amor a um esporte largamente difundido pela população, o sofrimento que, no caso concreto, é correlato ao prazer das pugnas de pugilismo, e as mazelas do cotidiano numa sociedade marcada por forte desigualdade social. A religiosidade popular vem associada a uma perspectiva religiosa de predestinação e, assim, o pathos é realçado também como aceitação dos sacrifícios impostos por Deus e pela religião. E, afinal, o "golpe de Job", vinha sob a forma de falta de ar, um sofrimento que lhe dava a sensação de asfixia de si. Pavor de dissolução do "Eu". Tonteira, pânico, tudo parecia ruir.

E a morte está dentro da vida ${ }^{37}$. Entretanto, no caso, um sentimento perpassa o texto como um todo. Trata-se do ressentimento, que Nietzsche (1844-1900) qualificara de o "pior dos sentimentos", talvez porque o sintamos como sentimento duplo ou dobrado na sua potência. Mais do que isso, o ressentimento é vivido como estranho sacrifício que cheira a passado que não se consegue superar como sina do destino que introduz a discórdia por via não plenamente consciente.

O personagem julga que este afeto vem cotelado pelo ódio, mas transferido para outra época por misteriosa transformação extra-natural. Assim, como num efeito de ilusão próprio, porém, da ideologia, vê-se transportado das "calles e vielas, de casas baixas, de um só pavimento, de telhados desiguais, com beirais sombrios, casas em negro e ocre, ou, grande solares, edifícios claustreados ..."38, para "as mesmas ruas, na capital do Novo Reino, dos Ouvidores, dos Vice-Reis" ${ }^{\prime 39}$, ou seja para o período colonial. O colonialismo faz-se de vetor para o ódio acumulado que vem associado a uma mulher velha e índia, que viajava num bonde de Bogotá ${ }^{40}$. Esses bondes eram o orgulho da cidade colombiana, "belos e confortáveis, de um vermelho sem tisne e com telhado prateado. Esse tranvia ia muito longe, até os confins da cidade". Sem que se soubesse o porquê, a mulher idosa e

\footnotetext{
${ }^{36}$ Ibidem, p. 267.

${ }^{37}$ Alusão a uma frase do poeta Fernando Pessoa.

${ }^{38}$ Ibidem, p. 263.

${ }^{39}$ Ibidem, P. 274.

${ }^{40}$ Ibidem, p. 274.
} 
indígena, mas certamente afrontada por algum motivo que só ela podia ver o agravo, se indignava e replicava sabe-se lá a quem. Todavia, a cada imprecação dava um tom de indignação moral que se eternizaria para sempre nas lembranças do personagem.

Ela cheirava os volumes da afronta, mastigava-a. Via-a vibrar os olhos, teve um rir hienino. Era uma criatura abaçanada, rugosa, megeresca, uma índia de olhos fundos. Daí começou a bramas suas maldições e invectivas. Essa lívida de lógica tinha em si a energia dos seres perversos, irremissiva. Clamava, vociferoz, com sua voz fora de foco, vilezas e imprecações, e fórmulas execratórias, que jamais cessaria. Durou quase uma hora, tanto tempo que a viagem, tão longa. Ninguém ousava olhá-la, ela era a boca de um canal por onde mais ódio se introduzia no mundo. Doem-se os loucos, apavoram-se. Até que ela desceu, desapareceu, ia já com longa sombra. Aquela mulher estará eternamente bramindo. Doo-me ${ }^{41}$.

A descrição é mais que pungente. Ela expressa uma raiva inaudita, que nunca se vira por aquelas plagas; de um tom ao mesmo tempo estarrecedor, mas também maravilhoso e desconcertante. Havia naquela mulher algo de extraordinário, de magia, de erupção iracunda incontrolável.

Ora, esse comportamento não fazia o gênero do protagonista, ensimesmado no seu isolamento, embora não privado da consciência e da reflexão. Mas fato é que os bondes encantatórios, "com um vermelho sem tisne e com telhados de prata", foram alvo da fúria da população bogotana quando do levante Bogotazzo. Muitos veículos foram queimados e se consumiram em altas labaredas laranja-azulecidas propiciando um espetáculo de rara e sinistra beleza. Tal a marca desses bondes, trade mark do imperialismo amalgamado ao colonialismo, do ressentimento marcado pela brutal exploração do Capital sobre o Trabalho das gentes. Os tais bondes, belos e confortáveis, que marcaram um levante explosivo dos miseráveis e das classes populares, acabaram sendo tirados de circulação e posteriormente desapareceram por substituição de outros meios de transporte.

Outro episódio terrível e sugestivo que a lembrança do personagem faz alusão em "Páramo", e que se refere ainda a uma figura feminina no lugar central, é a notícia de emparedamento de uma mulher; notícia que parece lançada ao léu no texto, mas que vamos interpretar num movimento inverso ao do item anterior. Se lá partimos do original para a tradução, aqui vamos partir da tradução em espanhol para o original em português. Foi o tradutor colombiano e bogotano Bairon Oswaldo Vélez Escalón quem por primeiro localizou no autor Cordovez Moure ${ }^{42}$ o curioso texto que oferece um exemplo extremo de

\footnotetext{
41 Ibidem.

${ }^{42}$ Cordovez-Moure, José Maria (1962). Reminiscencias de Santa Fé y Bogotá, Madrid: Aguillar.
} 
crueldade. Mas vamos primeiro ao original em espanhol, crônica de 1899, intitulada "Custodia o la emparedada":

No bien se hubo derribado lo suficiente para observar lo que existiera en el fondo de aquela cavidade, vieron - que horror! - uma momia médio envuelta em asqueroso sudário que hacia sobre um lecho de estiércol y entre millares de gusanos blancos que pululaban por todas partes. Lo más horrible de aquel repugnante espetáculo era, que isso que tenia alguna forma parecida a la espécie humana, hacia débiles movimientos com las manos em actitude depercatoria, implorando compasión y dirigiendo a todos miradas lastimosas y tiernas com ojos apagados pero expressivos, de donde brotavan gruesas lágrimas ${ }^{43}$.

Agora vamos à narrativa na forma que Ihe dá Guimarães Rosa:

Aqui, faz muitos anos, sabe-se que uma mulher, por misteriosa maldade, conservou uma mocinha emparedada, na escuridão, em um cubículo de sua casa, depois de mutilá-la de muitas maneiras, vagarosa e atrozmente. Dava-lhe, por um postigo, migalhas de comida que previamente emporcalhava, e, para beber, um mínimo de água, poluída. Não tivera motivo algum para isso. E, contudo, quando, ao cabo de meses descobriram aquilo por acaso, e libertaram a vítima - restos, apenas, do que fora uma criatura humana, retirados da treva, de um monturo de vermes e excrementos próprios - o ódio da outra aumentara, ainda ${ }^{44}$.

Uma estória escabrosa como essa, que função teria senão a de oferecer um flagrante de luz que, como sintoma, remeteria a outras reminiscências?

Logo a crônica anuncia o que de similar sente o protagonista: o emparedamento em vida, ser mantido prisioneiro em custódia (recorde-se Baden-Baden).

Entretanto, permitimo-nos interpretar na crônica tipo "mundo-cão/ planeta bizarro", as notícias da barbárie do nazismo, especialmente contra os judeus (mas não só), que então eram anunciadas e chocavam a opinião pública mundial. Muito desse barbarismo não havia sido vivido tão de perto pelo autor quando então atuava como diplomata na Alemanha? O imaginário fantasmagourava na sua plenitude [...] E acabamos por utilizar uma expressão marcante, neologismo do qual Guimarães Rosa lançará mão logo adiante. Alguns outros neologismos estarão presentes para assinalar o espanto e o lúgubre, associados à morte: lugubrúvio, gelinvérnico, estranhifício, passadidade, clã-destino, discordioso, entreconsciente.

E pela terceira vez é a mulher quem surge no horizonte do personagem; não uma mulher qualquer, mas precisamente aquela que o amava. Adivinhara pela letra, já no pequeno envelope. Recebera a carta em casa, quando certo dia chegara em casa

\footnotetext{
${ }^{43}$ Ver a citação em espanhol apud Vélez Escalón, Bairon Oswaldo (2012). Op. Cit., p. 67.

${ }^{44}$ Rosa, João Guimarães (2001a). "Páramo". Op. Cit., p. 275.
} 
tomado pela estafa da perseguição implacável do seu duplo. "Apesar dos pesares tinha que chamá-la tristemente de casa". ${ }^{45}$ Um trecho da carta dizia: "[...] tem horas, penso em você, como em alguém, muito querido, mas que já morreu [...'. 46

No trajeto, uma alegria singular e única. Comprara um livro por uma bagatela, o qual passará a ser designado como $O$ Livro. Supunha-o um livro de poemas. Tomava-o, num primeiro momento, para passar o tempo tedioso que vivia, imaginando que poderia ser-lhe útil em alguma ocasião. Logo passa a considerá-lo quase como objeto de devoção salvífica, um amuleto. A partir de então, carregava-o consigo. Entretanto, não ousava lelo, Portava-o fechado como um penhor, um refém. Algo de misterioso ali estaria escondido.

III

O poeta e romancista do idioma francês Jules Laforgue (1860-1867), embora nascido em Montevidéu, referiu-se assim ao pintor Arnold Böcklin (1827-1901): “On reste stupéfait de cette unité dans le rêve, / de cet aveuglement dans le fantastique, / de ce naturel impeccable dans le surnaturel'. E de Arnold Böcklin são os dois quadros - "A Ilha dos Mortos" e "Vita Somnium Breve" - referidos explicitamente no conto "Páramo".

Nascido e falecido na cidade de Basileia, o pintor suíço formou-se em pintura na Academia de Düsseldorf. Esteve em Paris, Roma e Florença. Para o que nos interessa, Böcklin retirou elementos da natureza presentes nos quadros de pintores quinhentistas e seiscentistas do Norte da Europa, como Salomon von Ruysdael, Albrecht Dürer e Mateus Grünewald, e buscou vinculá-los a temáticas próprias do romantismo alemão. Isso deu origem a pinturas como "A Ilha dos Mortos", de 1880, uma das suas obras mais conhecidas, e que ele caracterizou como "uma imagem para sonhar", embora o nome pelo qual a pintura é conhecida tenha sido dado por um comerciante de arte. Todos estes aspectos, reforçados pelos elementos que Böcklin retirou do movimento simbolista em França, contribuíram para a influência exercida sobre pintores do expressionismo e do surrealismo, como Salvador Dalí e Giorgio de Chirico. O trabalho de Böcklin desenvolveuse na Basiléia e em Munique, tendo-se destacado também na pintura mural (as escadas do Kunstmuseum de Basileia) e de retratos (a atriz Jenny Janauschek). Algumas das suas

\footnotetext{
${ }^{45}$ Rosa, João Guimarães (2001a). "Páramo”. Op. Cit., p. 273.

46 Ibidem.
} 
obras encontram-se nos principais museus da Alemanha (Berlim, Munique), Suíça (Basiléia) e Estados Unidos (New York).

No primeiro quadro "o fantasmagórico e estranhamente doloroso maciço de ciprestes [...] [...] para lá vai a canoa com o obscuro remador assentado [...]"47. Repare-se que as falésias tumulares estão fortemente iluminadas, por entre as quebras dos rochedos. E também está no foco luminoso (de onde virá aquela luz?) um vulto alto e ereto envolvido num sudário branco a indicar a entrada do morto na mansão dos mortos. Este é levado na canoa pelo remador, cuja luz não o alcança. O quadro, como diz o autor, recorda uma mistura do "negrego dos eucaliptos, seu evocar de embalsamentos, as partículas desses cheiros ${ }^{\text {,48. }}$.

As tonalidades de claro-escuro estão admiravelmente combinadas na pintura, provocando um forte impacto emocional. São escuras as águas por onde navega 0 canoeiro, as nuvens e o firmamento, bem como a mancha de ciprestes. De um tom amarelo-claro são os mausoléus propriamente ditos, dando-nos a impressão da "vida" no reino dos mortos.

Já no segundo quadro duas crianças pequenas e nuas brincam na relva verde à beira de uma sepultura. Ao fundo, um mausoléu com figuras em destaque. Para os olhos do personagem que tem em mente a pintura, "a relembrança da sua maestra melancolia" ${ }^{49}$. Não se trata tanto de uma obra maestra do artista, mas sim uma obra maestra acerca da melancolia, que o justifica. O mestre parece ser mesmo a melancolia.

As imagens de Arnold Böcklin chegam ao protagonista em situação de sopor, torpor e sonolência. São as horas medonhas da noite onde ele está preso às resistências da insônia. Em ambas as obras, podemos detectar uma arqueologia do pathos que remete a um "presente dilatado em que o passado cresce à nossa frente e o futuro consta como uma visão do passado numa perspectiva já presente em Warburg". 50 Para esse autor, vale recordar que as formas patéticas (pathosformel) "condensavam figuras e gestos, conteúdos e expressões, carregando emoções e afetos primitivos que pudessem irromper na continuidade histórica ao manifestar simultaneamente algo original, novo, e a retomada

\footnotetext{
${ }^{47}$ Ibidem, p. 271.

${ }^{48}$ Ibidem.

49 lbidem, p 273.

50 Didi-Huberman, Georges apud Schollhammer, Karl Erik (2012). Op. Cit., p. 5.
} 
e repetição do passado"51. Didi-Huberman o chama um "historiador a beira do abismo"52 $\mathrm{e}$ o próprio Warburg se designa a si próprio como um "sismógrafo da alma".

Arnold Bocklin (1827-1901) "A Ilha dos Mortos"

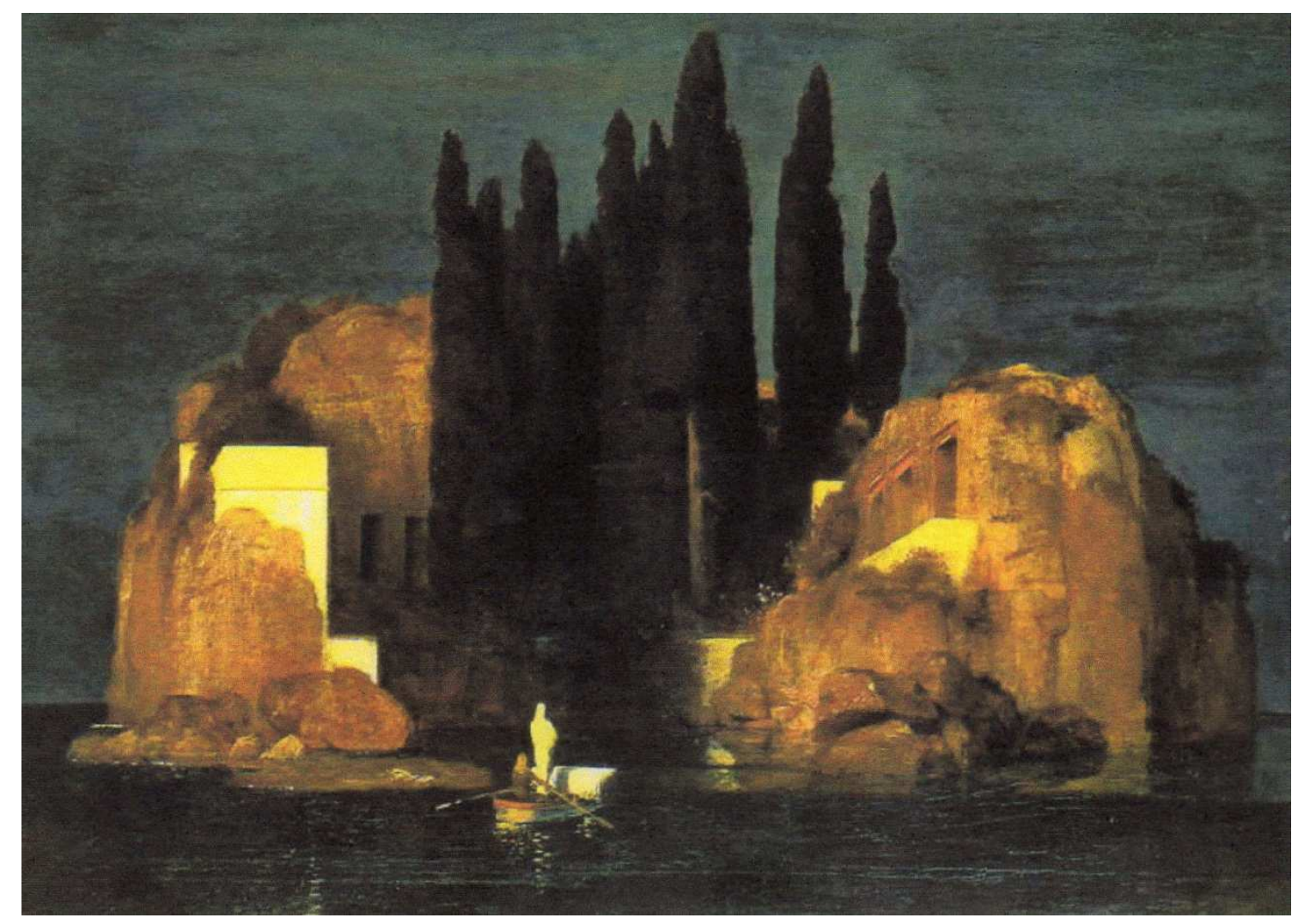

${ }^{51}$ Schollhammer, Karl Erik (2012). Op. Cit., p. 5.

52 Didi-Huberman., Georges. (2009). Op. Cit. 


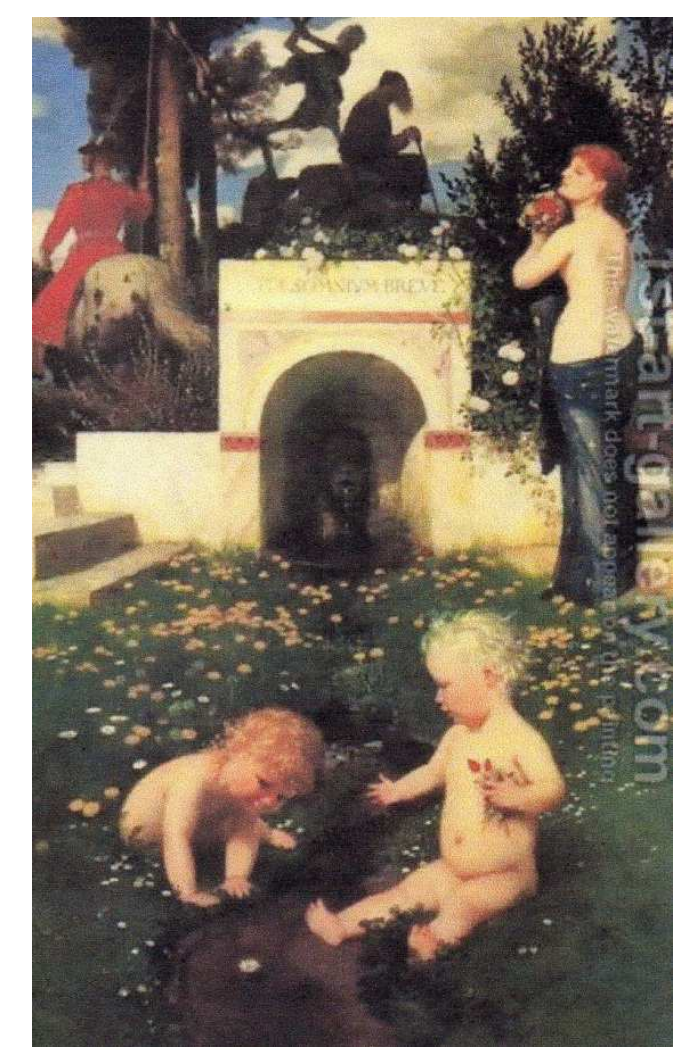

Arnold Bocklin - Vita Somnium Breve

A maneira como a pintura de Arnold Böcklin entra no conto Páramo é sugestiva merece breve digressão.

Em 1897 Sigmund o Freud fora indicado para o corpo docente da Faculdade de Medicina da Universidade de Viena. Mas o processo ficou em suspenso por quatro longos anos no Ministério da Cultura. Caracterizou-se uma suspeição de que Freud sofrera de velado preconceito - talvez anti-judaico - e de que haveria necessidade de alguma intervenção pessoal junto ao Ministério. Primeiramente Freud recorreu a Elise Gomperz, sua paciente há quinze anos. Ela era esposa de Theodor Gomperz, famoso pensador liberal clássico. Não deixa de ser interessante recordar que Sigmund Freud, quando era estudante, traduzira para o alemão o ensaio "A sujeição das mulheres", de Stuart Mill para a edição germânica das obras reunidas de Mill que estava sendo organizada por Theodor Gomperz. Mas ele não chegou a se envolver pessoalmente e a intervenção de mulher dele não obteve resultado prático. Freud trabalhara arduamente na interpretação das causas pelas quais sua nomeação não saía. Ele valorizava o mérito e buscava uma explicação mais dentro de si do que no Outro. Quando desconectou o pedido do par 
autonomia/submissão do sujeito ${ }^{53}$, ousou assumir e sustentar o seu desejo; pedir por ele. Assim, Freud foi então buscar proteção na baronesa Marie Ferstel, Ela era esposa de diplomata e nora de Heinrich Ferstel que construíra a nova universidade. A baronesa mediou a relação com Von Harte, então Ministro da Cultura em Viena. A baronesa, também analisanda de Freud, agiu rápido, entrou em contacto com Von Hartel, fez o pedido e prometeu-Ihe em troca uma pintura de Arnold Böcklin para a "Galeria Moderna" que logo seria inaugurada e era a paixão de Von Hartel. Esse artista "era aceito pelos tradicionalistas como um realista clássico e reverenciado pelos secessionistas como pioneiro da modernidade, pelas suas pinturas ligadas à vida e à morte" ${ }^{\prime \prime 4}$. Ele fazia uma ponte entre os grupos que apoiavam e aqueles que rejeitavam o pintor Gustav Klimt. Certamente que um quadro de Arnold Böcklin cumpriria uma função política. Todavia o processo já andara; a baronesa não conseguiu o tão sonhado quadro e quando finalmente a nomeação saiu publicada pelo imperador, em março de 1902, outra pintura, de Emil Orlick, substituiu o Böcklin prometido. Desta vez, um dos pintores secessionistas mais conservadores ${ }^{55}$.

Freud soube da notícia em primeira mão e pela baronesa, que foi logo avisada pelo ministro. O interessante a destacar é o quanto Arnold Böcklin evidenciava a questão de vida ou morte que fora, certamente, intensamente vivida por Freud por ocasião da realização desse desejo de ser docente universitário e em relação à figura paterna. Assim, a referência a Böcklin no conto "Páramo" se transforma numa poderosa metáfora referida ao desejo e à ética que lhe corresponde.

\section{IV}

Uma ocasião Guimarães Rosa disse que "a estória não quer ser história"56, certamente para marcar o imaginário como traço presente, por exemplo, no conto ou no romance, e completou "o livro pode valer muito pelo que nele não deveu caber" 57 .

Texto literário e contexto histórico se influenciam reciprocamente, mas não se reduzem um ao outro. A proposição de Jacques Lacan é a de que a realidade resulta da

\footnotetext{
${ }^{53}$ Ver Schorske, Carl (1989). Viena fin de siècle: política e cultura, São Paulo: Companhia das Letras. Especialmente o capítulo IV "Política e Parricídio", p. 179-201.

${ }^{54}$ Ver Schorske, Carl (1989). Op. Cit., p.235.

${ }^{55}$ Ibidem, ibidem.

${ }^{56}$ Ver Prefácio do autor intitulado "Aletria e Hermenêutica". In Rosa, João Guimarães (2001b). Tutaméia (terceiras estórias), Rio de Janeiro: Nova Fronteira, p. 29.

${ }^{57}$ Ibidem, p. 40.
} 
tríade RSI (Real, Simbólico, Imaginário). Esses três registros relacionam-se entre si como três aros entrelaçados onde o liame cortado entre um e outro aro desata os liames todos os aros e liberta os vínculos entre eles. Mas recordamos que a realidade não se confunde com o Real ${ }^{58}$.

Assim, sublinhamos que o texto não se esgota no contexto. Todavia, podemos buscar no texto aspectos e rastros do contexto. $E$ vice-versa para ambas as circunstâncias. Talvez, no limite, pudéssemos falar em história subjetivada presente, mais ou menos, na estória e a história, propriamente dita, presente no ofício do historiador como objetivo nunca alcançável.

O sufoco, o emparedamento, a angústia, a morte em vida, o exílio, o desterro, que falam da experiência subjetiva do protagonista parecem também ecoar o livro de poesia "Regreso de la muerte", de Tomás Vargas Osório (1908 - 1941) publicado em 1939 nos "Cuadernos de Piedra y Cielo", conforme sugere Vélez Escalón ${ }^{59}$.

Vejamos esse fragmento:

\section{[...] ¿De qué trémula linde} retorno, el corazón maravillado?

¿Qué boscajes ilímites me dieron

la fresca miel de sus rumores blandos?

¿Qué pájaros quebraron en mi oído

sus divinos cristales encantados?

- ¿Viajero, de dónde vienes que así sonríes callado?

¿Qué canción escucharon tus oídos, qué fruto gustaron tus labios?

¡Ah, que no era el reinado de la larva obscuro, yerto y hórrido! Que no era el negro paraíso del gusano, sino una deleitosa primavera!

Libre de ceño adusto y descarnadasonrisa horrible, era la muerte bella como la esposa deseada que a una pasión más pura nos convierte $[\ldots]^{60}$.

E ao final do poema:

[...] ¿Viajero, de dónde vienes, que así sonríes callado? ¿Qué canción escucharon tus oídos, qué fruto gustaron tus labios?

- Vengo de la Comarca de la Muerte donde el rostro de Dios iluminado se reflejó en mi corazón suspenso, por yelo y fuego suyos rescatado $[\ldots]$

\footnotetext{
${ }^{58}$ Quinet, Antonio (1995). "O espelho e o quadro", ver "O imaginário: narciso e o espelho". In Imagem Rainha (parte I), EBP, Rio de Janeiro: Sete Letras.

${ }^{59}$ Vélez Escalón, Bairon Oswaldo (2012). Op. Cit., p. 65.

${ }^{60}$ Osório, Tomás Vargas (2008). Regreso de la muerte, Bucaramanga: Dirección Clutural, p. 27-33.
} 
Parece-nos interessante que uma chama de esperança sustente esse retorno da morte, que não é mais do que o imaginário de ressurreição. Não é isso que o personagem de "Páramo" acaba por sustentar?

Pensamos que podemos ler "Páramo" desde o ponto de vista da estranheza inquietante vivida pelo protagonista enquanto estrangeiro, clandestino, intruso, alheio àquele território nas alturas. Daí porque fomos buscar o diálogo entre a tradução em espanhol e o conto em português. Temos em mira a recepção de uma escritura plena de neologismos e palavras novas inventadas por Guimarães Rosa. Também palavras em outros idiomas e mesmo alguns anacronismos. E há outros signos não fonéticos a serem recepcionados pelo tradutor. No caso, Bairon Oswaldo Vélez Escallon que, por um lado, sente-se homenageado uma vez que é colombiano e bogotano de nascimento; por outro lado, nem sempre reconhece em "Páramo" aquela que é a sua Bogotá. Assim, o autor terá que lidar com certa ambivalência presente em qualquer estrangeiro que um qualquer queira acolher e não rechaçar sem mais. É oportuno reproduzir o final das considerações feitas por Vélez Escallon ao fim das suas reflexões pulicadas na Revista Tusaaji - $A$ Translation Review, publicada em Toronto, Canadá.

El intruso se introduce por fuerza, por surpresa o por astucia; em todo caso, sin derecho y sin haber sido admitido de antemano. Es indispensable que en el estranjero haya algo del intruso, pues sin ella perde su ajenidad. [...] Es esto lo que se trata de pensar, y por lo tanto de practicar: si no, la ajenidad del estranjero se reabsorbe antes que este haya franqueado el umbral, y ya no se trata de ella. Recibir al estranjero también también debe ser, por cierto, experimentar su intrusión [...] [Cierta] corrección moral supone recibir al estranjero borrando em el umbral su ajenidad: pretende entonces no haber admitido en absoluto. Pero el estranjero insiste, y se introduce. Cosa nada fácil de admitir, ni quiçá de concibir $^{61}$.

Agora vamos substituir toda vez que aparece a expressão "estranjero" pela expressão "muerte":

El intruso se introduce por fuerza, por surpresa o por astucia; em todo caso, sin derecho y sin haber sido admitido de antemano. Es indispensable que em la muerte haya algo del intruso, pues sin ella perde su ajenidad. [...] Es esto lo que se trata de pensar, y por lo tanto de practicar: si no, la ajenidad de la muerte se reabsorbe antes que este haya franqueado el umbral, y ya no se trata de ella. Recibir la muerte también también debe ser, por cierto, experimentar su intrusión [...] [Cierta] corrección moral supone recibir la muerte borrando em el umbral su ajenidad: pretende entonces no haber admitido en absoluto. Pero la muerte insiste, y se introduce. Cosa nada fácil de admitir, ni quiçá de concibir.

\footnotetext{
${ }^{61}$ Nancy, Jean-Luc (2006). El Intruso, Buenos Ayres: Amorrortu, p. 11-13 apud Vélez Escalón, Oswaldo Bairon (2012). Op.Cit., p. 71.
} 
Estrangeiro e morte tem, pois uma certa equivalência. É a chave da questão. A morte aparece sempre como intrusa; não a desejamos, não a queremos. Mas ela é invasora e se impõe com sua exterioridade. Com S. Freud poderíamos chamar isso de Das Hunheimlich que Paulo Cesar de Souza 62 traduz como "o estranho inquietante". A ambivalência com que a tradução hispânica recepciona um texto estrangeiro como "Páramo" é a mesma com que cada leitor recepciona a experiência de des-subjetivação vivida pelo protagonista enquanto "morte imperfeita". Já para Marco Casanova, tradutor de Zorn und Zeit, de Peter Sloterdijk, e seguindo-se o sentido etimológico da palavra

humheinlich designa aquilo que não (un-) pertence à terra natal (Heim), aquilo diante do qual não nos sentimos em casa. Por isso, o termo também abarca de maneira derivada o significado de algo desconhecido, lúgubre e inquietante, assim como de algo ingente, gigantesco. Para preserva a riqueza desse termo em sua dimensão mais original, escolhemos a palavra 'descomunal' porque ela também descreve a experiência de um confronto com algo fora do comum e abarca alguns dos matizes significativos do origina ${ }^{\beta 3}$.

Esse caráter invasor da "morte imperfeita", fiel à expressão de Guimarães Rosa, tem algo de descomunal. A experiência dessa morte é algo da vivência funda de um sofrimento que não acaba, mas que de repente muda e transforma-se em alegria das mais genuínas.

Enquanto tal não ocorre, temos a angústia. Para Elias Canetti “a hipocondria é o troco miúdo da angústia e a angústia, para distrair-se, procura e encontra nomes"64. Todavia, para Manoel Berlinck, o "entranho inquietante" aparece na clínica como "obscuro surpreendente". E uma tal relação com esse "obscuro surpreendente" afastaria o "conhecimento objetivo, afastaria igualmente o conhecimento intuitivo e o conhecimento por fusão mística. O conhecimento como neutro, diz 0 autor, pressuporia uma relação estranha a toda exigência de identidade e de unidade, ou mesmo de presença". Assim, [...]

[...] relacionar-se com o obscuro surpreendente sem desvelá-lo significa muito precisamente que o enigmático no neutro não pertence à luz. Pertence a uma 'região' estranha a essa, a descoberta que se realiza na e pela luz. O obscuro surpreendente não cai sob o olhar, sem estar, no entanto, escondido do olhar:

\footnotetext{
${ }^{62}$ Paulo Cesar de Souza é o tradutor de Freud para a obra de Freud pela Companhia das Letras, São Paulo.

${ }^{63}$ Ver a tradução de Marco Casanova para Zorn und Zeit, de Peter Sloterdijk, São Paulo: Estação Liberdade, 2012. Especialmente p. 11 nota 1 do tradutor.

${ }^{64}$ Canetti, Elias Canetti (1988). O outro processo (as cartas de Kafka a Félice), Rio de Janeiro: Espaço e Tempo, 1988. Ver ainda Zischler, Hanns (2005). Kafka vai ao cinema, Rio de Janeiro: JZE
} 
nem visível, nem invisível ou, mais exatamente, desviando-se de todo o visível e de todo o invisível. O obscuro surpreendente, aquele para o qual a clínica nos desperta, é muito mais imprevisível do que pode sê-lo o futuro, mesmo 'o futuro não predito', pois tal como a morte ele escapa a toda apreensão, exceto à fala, mas na medida em que esta não é uma apreensão, não é uma captura. Eis então o essencial na clínica: falar o obscuro surpreendente, acolhe-lo na fala mantendoo obscuro é precisamente não apreendê-lo, não compreendê-lo, é recusar-se a identificá-lo por essa captura 'objetiva' que é a visão, a qual captura, embora à distância. Viver com o obscuro surpreendente diante de si (o que significa dizer também: viver diante do obscuro e diante de si como obscuro) é entrar nessa responsabilidade da fala que fala sem exercer qualquer forma de poder, inclusive esse poder que se realiza quando olhamos, já que, olhando, mantemos sob nosso horizonte e em nosso círculo de visão - na dimensão do visível/invisível - aquilo e aquele que está diante de nós. Clinicar é, sem vínculo, vincular-se ao obscuro surpreendente e perigoso, ao caso clínico como fundamento da terapia e da pesquisa psicopatológica ${ }^{65}$.

Nos termos propostos por J. Lacan e aludindo à clínica em intenção (intensión) versus a clínica em extensão (extensión), poderíamos dizer que um conto literário como esse "Páramo" nos solicita em igual medida a vincularmo-nos, sem vínculo, ao obscuro surpreendente e perigoso da des-subjetivação como morte imperfeita? ${ }^{66}$

Mas devemos recordar que a Escola dos Annales já propunha desde o início do século XX uma aproximação do pathos ao ethos. Ela propôs tanto o uso da antropologia e da sociologia (Durkheim), quanto da psicologia coletiva (Charles Blondel). Em "Apologia da História", Marc Bloch nos assegura "o gosto pelo estranho e a volúpia das coisas singulares que mobiliza a pesquisa histórica e se configura como uma busca do Outro dentro de nós mesmos"67.

A história [...] tem seus gozos estéticos próprios, que não se parecem com os de nenhuma outra disciplina. É que o espetáculo das atividades humanas, que forma seu objeto específico, é mais que qualquer outro feito para seduzir a imaginação dos homens. Sobretudo quando, graças ao seu distanciamento no tempo ou no espaço, seu desdobramento se orna de sutis deduções do estranho (...) Resguardemo-nos de retirar de nossa ciência sua parte de poesia. Resguardemonos, sobretudo, já surpreendi essa sensação em alguns, de enrubescer por isso. Seria uma espantosa tolice acreditar que, por exercer sobre a sensibilidade um apelo tão poderoso, ela devesse ser menos capaz de satisfazer também nossa inteligência $^{68}$.

\footnotetext{
${ }^{65}$ Berlinck, Manoel Tosta (2012). "O Neutro". In Tempo Psicanalítico, Rio de Janeiro, v. 44, n. 1, p. 183-199.

${ }^{66}$ Cerqueira Filho, Gisálio (2006). Op. Cit.

${ }_{67}$ Cerqueira, Marcelo Neder (2012). História da Memória, Tradição Oral e Vídeo História: reflexões metodológicas, PPGH/ICHF-UFF, Niterói. Mimeo.

${ }^{68}$ Bloch, Marc (2002). A Apologia da História ou o Ofício do Historiador, Rio de Janeiro: Zahar, p. 44 apud Cerqueira, Marcelo Neder (2012). Op. Cit., p. 28.
} 
Multiplicam-se sentimentos e palavras para dar conta desta "emoção inconsciente"69 de um mundo funéreo desconhecido, que você, todavia, não pode conceber. Dramática contradição, onde:

Todos se castigam. É terrível estar morto, como às vezes sei que estou - de outra maneira. Com essa falta de alma. Respiro mal; o frio me desfaz. É como na prisão de um espelho. Num espelho em que meus olhos soçobraram. O espelho tão cislúcido, somente. Um espelho abaixo de zero ${ }^{70}$.

Por vezes, entretanto, devemos estar atentos para o absoluto da solidão. Não eram apenas a circunstância e a vivência de encarceramento naquelas alturas. Era mais, era o sentimento de dilaceração do "Eu" intensamente vivido.

Entre os que eram meus, que tinham sido em outro tempo, tão recente, algum tanto meus - parentes, amigos, companheiros, conhecidos - haviam ficado alhures, imensamente em não, em nada, imensamente longes, eu os tinha por perdidos. E tudo parecia para sempre, trans muito, atrás através. Sei quer era a morte - a morte incoativa - um gênio imóvel e triste, com a tocha apagada voltada para baixo, e na ampulheta, o vagaroso virar do tempo; e, eu, menino triste que a noite acariciava ${ }^{71}$.

Ainda assim, a hipótese da superação não estava totalmente excluída. Por isso o alento quando adiante encontra "em sotaina, sob a chuvinha (...) um padre pequeno, baixote, sob imenso guarda-chuva (...) que, em sua loucura, dera para usar somente objetos de tamanho enorme. E gritava: Y olé y olép. ${ }^{72}$ Seguia-lhe um cortejo fúnebre que, no imaginário, seria formado de:

[...] confessores, de lábios finos; a viúva dos malefícios; o cavaleiro equiparado, o frade moço que não pode esquecer da mulher amada (...) condenado prisioneiro perpétuo num aljube; os homens que recolhem os corpos mortos das rainhas e princesas, no podridero do Escorial; o fabricôco de capuz ${ }^{73}$.

Não sem razão, projeta então uma imagem forte: "(...) pinto aquele da XII lâmina do Tarô, o homem enforcado - o sacrifício voluntário, gerador de forças, esse é o que me representa". A carta XII do Tarô contém um complexo simbolismo, mostrando a imagem de um homem suspenso por um dos pés, amarrado em uma viga de madeira, apoiada

\footnotetext{
${ }^{69}$ Freud, S. (1996). "O Inconsciente". In: História do Movimento Psicanalítico, trad. Jayme Salomão, Rio de Janeiro: Imago, v. 14, p. 165.

${ }_{71}^{70}$ Rosa, João Guimarães (2001a). "Páramo". Op. Cit., p. 276.

${ }^{71}$ Ibidem, p.269.

${ }^{72}$ Ibidem, p. 275

${ }^{73}$ Ibidem, p. 275.
} 
entre duas árvores, e cada uma com seis ramos cortados, significando o mundo material. O que chama mais atenção é o ar reflexivo da figura, sempre presente em todas as representações dessa carta. O enforcado não o é pelo pescoço, e sim pelo pé, e mantém os olhos abertos e, numa visada, quebra-se o sinistro da morte por enforcamento. Daí a hesitação entre os tarólogos. Abaixo a XII carta do Tarô: o Enforcado.

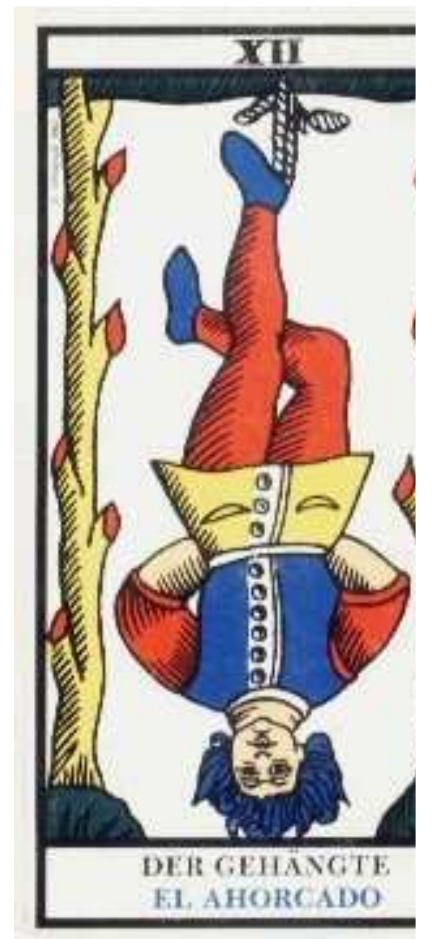

As interpretações dos tarólogos variam: para alguns, a carta é sempre negativa, pois indica um período de inércia, ou de hesitação. Também revela apego a ideias pré-concebidas, e visão distorcida das coisas. Mas há, por outro lado, leituras positivas segundo as quais a carta indicaria um período de reflexão, ou um tempo de recolhimento necessário a novas definições de rumo. Esse sentido positivo parece mais rico. Ao invés da morte por asfixia esperável no enforcamento, temos uma inversão de sentido na leitura da carta, como é invertida a figura pendurada. Colocar a cabeça em baixo e não em cima, ou virar as coisas de cabeça para baixo pode sugerir tanto a perda de prestígio do pensamento, como a necessidade de olhar de outro ângulo. Nesse sentido, a visão distorcida vista como problema pela leitura negativa da carta pode se revelar positivamente como um modo novo de ver. Essa leitura representa melhor (a meu ver), o texto de Rosa ${ }^{74}$.

74 Pereira, Maria Luiza Scher (2007). "O Exílio em "Paramo" de Guimarães Rosa: dilaceramento e superação”. In Psicanálise \& Barroco - Revista de Psicanálise, v.5, n.1, p. 18. 


\section{VI}

"O samba é meu dom / É no samba / que eu quero morrer, / de baquetas nas mãos" ${ }^{\prime 75}$. Não é esse o último desejo do artista? E também o do intelectual? Morrer abraçado no seu dom? Guimarães Rosa protagonizou esse recôndito do desejo, mas não pode realizar no personagem de "Páramo". Afinal, de "morte imperfeita" se tratava. As baquetas estão para as últimas batidas de samba como o enigmático livro e correspondente última leitura estão para os últimos suspiros.

O personagem parece assegurar veracidade a Karl Marx redivivo. O pensador, filósofo e estudioso da Economia Política já dissera que todas as gerações mortas parecem oprimir como um pesadelo os cérebros dos vivos. Tal o sentimento vivido pelo protagonista nos páramos da cordilheira andina e para o qual concorria a neblina, o vento, a altitude, o ar rarefeito, a angústia da solidão. Acostumara-se, contudo, aquele sofrer. Chorava e muito, com bastante constância. O médico judeu que o medicara, já prevenira que isso ocorreria, fruto do soroche. Dissera-Ihe inclusive que, na circunstância, faria bem não segurar o pranto. Que chorasse e que desse caminhadas a passos pequenos. Faria bem naquelas alturas. Assim fizera e, a despeito de tudo, se não se acostumava àquela experiência, tinha em mente a possibilidade de "levantar o desterro, conseguir a desassombração"76. A esperança não o deixara. Isso, não! E de uma forma inesperada, desde quando se aplicara à noção de que um morto não poderia temer mais as adversidades futuras, mas apenas o morrer mais ... eis que vislumbrara a estrela-daguarda, a sua estrela-da-guarda. Como surge a esperança? Sofria ainda, mas esperava ${ }^{7 .}{ }^{77}$. Não se intromete aí o impossível do Real lacaniano? Numa das crises inopinadas de choro que sempre diminuía a opressão do coração, fizera-se como um fantasma, pois as lágrimas não paravam de saltar dos olhos e correr pelas faces, boca, abundantes. Repentinamente fora salvo de maiores constrangimentos. Um pequeno alvoroço de pessoas, perguntas interrogativas, falatório, indicava que pelo meio da rua vinha um cortejo de enterro.

Vira ali a oportunidade de chorar sem vergonha ou temor, pois umas vinte pessoas participavam daquela espécie de procissão fúnebre, das quais quatro carregavam o

\footnotetext{
${ }^{75}$ Neves, Wilson das; Pinheiro, Paulo e Cesar (1996). "O samba é o meu dom". In Toque de Prima, Rio de Janeiro: Velas. Faixa 12.

${ }_{77}^{76}$ Rosa, João Guimarães (2001a). "Parámo". Op.Cit., p. 277.

${ }^{77}$ Ibidem, p. 277
} 
pequeno ataúde. Mas querendo não ser notado, colocou-se "o mais atrás, após todos, como um cachorro" ${ }^{\prime 78}$. Não um cão de raça, mas um desses cachorros vira-latas que costumam surgir quando menos esperamos.

A cena como um todo, ele representava-a como "um capricho de Goya" ${ }^{79}$ Los Caprichos são um punhado de oitenta gravuras do pintor espanhol Francisco Goya. Elas apontam para uma forte sátira da sociedade espanhola de fins do século XVIII. E de algum modo ele era parte daquilo: de roupas diferentes, logo vão perceber que ele é estrangeiro, de classe social diversa, está sem chapéu e ainda porta um livro. protagonista toma a si a circunstância toda. "Agora, choro por mim, por mim que estou morto, (choro) por todos os mortos e insepultos [...]".

A presença do protagonista nesta caminhada que, por fim, chega ao Cemitério Central, acaba por devolver-Ihe a consciência plena. De súbito, num átimo de segundo, ele está agora bem desperto e percebe-se querendo se safar daquele "insaluto hospite" 80 . Pretende agora escapulir e assim define o campo santo em que chegara:

O lugar onde eu viera esconder-me, meu transfúgio, era um ponto fechado entre lápides e cipestres, quase um ninho, só o exigido espaço, folhagem e pedra mausoléia, em luz oblíqua, em suma paz. Tudo ali perdera o sentido externo e humano, nem mesmo podia eu ler os nomes nos tituleiros, com as letras meio gastadas do uso do tempo. Nenhuma voz, nenhum som. Sim, eu me recolhera a um asilo em sagrado, passava-se em mim um alívio, de nirvana, um gosto de $\mathrm{fim}^{81}$.

Podemos presumir que o conto chegava ao fim. A imperfeita morte, sob a forma de uma ansiedade sem fim, configurara-se num pathos peculiar. Como então podia sentir-se tranquilo? A visão final rememora Arnold Böcklin e sua pintura insular: as lápides, os ciprestes enfileirados, a mausoléia em pedra, o foco de luz. Teria razão Eurípedes? "Não me surpreenderia, com efeito, fosse verdade: quem sabe a vida é uma morte, e a morte uma vida? ${ }^{82}$.

De fato, estamos diante de um anticlímax. Poderia ficar ali "num sossego infinito, imperturbado dos homens" ${ }^{\prime 83}$. O protagonista julga então que chegara o momento de abrir o livro que trouxera consigo e até então não conseguira nem folheá-lo. Um livro que comprara por tão baixo preço, alguns centavos. A hora de abri-lo era essa. Que segredo o

\footnotetext{
${ }^{78}$ Ibidem, p. 285

79 lbidem, p. 286.

${ }^{80}$ Rosa, João Guimarães (2001a). "Parámo”. Op.Cit., p. 287.

81 Ibidem, p. 287.

82 Citação de Platão in Geórgicas que precede o conto Páramo,

83 lbidem, p. 288.
} 
aguardava? Que mensagem o destino lhe reservava? Pensava sôfrego em tudo isso, entretanto, acaba por dizer resoluto a sim mesmo: não... ainda não; faria melhor, faria o sacrifício de abandoná-lo. Vale dizer, sem ler sequer uma de suas páginas. Foi o que fez. Largou o volume aos cuidados do imaginário de Bocklin, pois que o deixou à sombra de um cipreste verde-escuro e de uma lousa funérea. Estava, por fim, prestes a sair pelo portão do cemitério.

Nesse exato momento, eis que surge um dos passantes que acompanhara o cortejo: era homem "alto, magro, moço, tinha o ar lhano e decidido". ${ }^{84} \mathrm{O}$ diálogo é resumido em pouco mais de uma indagação crucial: "Señor, a usted se le há perdido esto..." 85 . E estende-Ihe o livro. Agora, a despeito de tudo, ali estava o livro, tal qual uma esfíngie a observá-lo. O personagem abre o livro ele ao acaso e surpresa ...

Nada escrito na obra de Rosa. O que se segue é um espaço em branco, que o autor não chegou a preencher. As últimas frases são: “(...) eu voltava para o que nem sabia se era vida ou se era a morte. Ao sofrimento, sempre. Até o momento derradeiro que não além dele, quem sabe?'

O mistério do livro permanecerá para sempre. Qual seria o livro? Qual página fora aberta? Qual fragmento seria lido no Cemitério Central? Esse espaço restou em branco porque Guimarães Rosa não teve tempo para concluir e completar, em face da morte súbita? Ou o autor poderia pretender o fim do suspense devolvendo ao leitor o preenchimento desse espaço lacunar. O livro como um caderno em branco?

Certamente esse livro misterioso para sempre pode valer muito pelo que nele não deveu caber...

Entretanto, retornamos à citação de Platão recolhida por Eurípedes nas Geórgicas: "não me surpreenderia, com efeito, fosse verdade: quem sabe a vida é uma morte, e a morte uma vida?"

\footnotetext{
84 Ibidem, p. 289.

${ }^{85}$ Ibidem, ibidem
} 
As Geórgicas são um conjunto de quatro livros escritos por Virgílio (70 a.C. - 19 a.C.), cada um deles com cerca de quinhentos versos. E é o mesmo Virgílio quem faz uma referência indireta nas Geórgicas que muitos estudiosos sugerem seja em relação a Lucretius (99 a.C. - 55 a.C.) e ao volume "A Natureza das Coisas", de sua autoria": "Felix, qui portuit rerum cognoscere causas Atque metus omnis et inexorable fatum Subiecit pedibus strepitunque Acherontis avari ${ }^{87}$.

Acqueronte pode ser aqui uma pista para a conclusão final. Trata-se de um rio do "mundo inferior", que Virgílio, e também Lucrécio, usam como símbolo da vida após a morte 88

No dia 17 de julho de 1899, S. Freud relatara através de carta ao seu amigo e confidente, Fliess, que escolhera o lema, isto é a citação de abertura, para o seu livro "A interpretação dos sonhos" que seria publicado no início do século XX e iria revolucionar o pensamento científico e mesmo a história social da cultura, especialmente no Ocidente ${ }^{89}$. Tratava-se da legenda latina Flectere si nequeo superos, Acheronta movebo (se não posso dobrar os poderes superiores, moverei o inferno, ou seja, o Rio Aqueronte). São palavras retiradas da "Eneida", de Virgílio, e pronunciadas por Juno, protetora divina da semita Dino, contra Enéas, fundador de Roma. Não tendo conseguido dobrar os superiores poderes de Júpiter, conseguindo consentimento para que Eneas desposasse Dino, Juno invoca Aleto, Fúria do inferno, para desencadear emoções possessivas de sexo e ataque militar no lado de Enéas e seus aliados. A descrição de Virgílio é aterradora: trata-se de um monstro bissexuado, na verdade uma mulher fálica; semelhante a uma Górgona fervilhante de serpentes negras e retorcidas. No livro "A interpretação dos sonhos", Freud não oculta, antes assinala que com esta comparação legendária ele quer representar as pulsões reprimidas.

Esta citação de Virgílio, que funciona como uma espécie de senha para falar do emprego de meios ameaçadores com implicações fortes de mudança, já fora utilizada anteriormente pelo pensador socialista Ferdinand Lassalle, na página de rosto do volume

\footnotetext{
${ }^{86}$ Virgílio. Geórgicas. 2490-92.

87 "Abençoado quem conseguiu encontrar a causa das coisas

E pisoteou todos os medos e os inexoráveis fados

E o rugido do cupido Acqueronte".

${ }^{88}$ Veja-se Gale, Monica (2009). Virgil and the Nature of Things: The Georgic Lucretius. And the Didatic Traditio, Cambridge: Cambridge University Press apud Stephen Greenblatt. The Swerve: How the world became modern. Vencedor do Premio Pulitzer de 2012.

${ }^{89}$ Cerqueira Filho, Gisálio (2002b). "Freud, a cultura e a política". In Revista Pulsional de Psicanálise, São Paulo, ano XV, n. 155, março, p. 55-66.
} 
de sua autoria e intitulado "A Guerra italiana e a tarefa da Prússia" (1859). Não se sabe se Freud apreciava ou até se teria lido esta obra. De todo modo, na referida carta a Fliess ele menciona que estava levando "Lassalle para as férias de verão" e é muito provável que fosse esta obra. Embora Freud não a mencione diretamente, e tão somente refira-se a Lassalle, fato é que coletâneas de textos políticos de Ferdinand Lassalle circulavam à época, e pelo menos uma, organizada por Erich Blum, incluía a "Guerra Italiana e a tarefa da Prússia" e fora publicada em Leipzig, 1899, ocasião em que Freud concluía nos arredores de Grinzing, Viena, no castelo de Bellevue, o manuscrito "A interpretação dos sonhos". Claro, Freud não precisava de Lassalle para referir-se a Virgílio, pois conhecia bem "Eneida", mas não deixa de ser um indício sugestivo, até mesmo como sintoma, na linha do que propõe a metodologia indiciária. Esta afinidade eletiva entre 0 ativista, militante político Lassalle e o médico psicanalista Freud, que como Édipo, realiza busca pessoal, moral e intelectual, aparentemente alheio à política e ao fato de que Édipo era um rei.

Precisamente por aqui, no real, no real da realeza - o que de mais imaginário neste simbólico? - se pega a intrincada tríade "lacaniana" RSI (Real, Simbólico, Imaginário), um dos fios da meada na relação entre psicanálise e política, Édipo e poder, Oedipus Rex na plenitude da cultura grega, fratura exposta na tragédia de Sófocles. Mas com certeza as afinidades eletivas entre Lassalle e Freud não se esgotam na coincidência da citação evocada de Virgílio. Em ambas as obras política e psicanálise se atam e desatam, encontram-se e desencontram-se em temas, questões, preocupações e ansiedades políticas de fim do século XIX que atestam a "catexe de Lassalle" e as "opções políticas de Freud"; assim mesmo, invertidas expressões a consagrar o fluido intercâmbio entre preferências político-ideológicas e vivências afetivas inscritas na matriz edipiana.

A nossa hipótese principal é essa: O protagonista de "Páramo" atesta a "catexe de Joãozito".

Todavia, sinta-se o leitor completamente à vontade para escrever no espaço em branco que João Guimarães Rosa não preenchera... Um texto pessoal que o grude ao real, até que a morte sobrevenha. De nossa parte, bem poderia ser um fragmento de poema que, ao acaso encontramos e compramos por uns poucos francos, às margens do Rio Sena, em Paris. Dizia assim: 


\author{
Ghislaine \\ Prénom germanique \\ qui signifie otage. \\ Les Ghislaine ne sont pas / \\ des martyres mais des fi- \\ gures de proue. I \\ Elles seront des modè- \\ les dans leur travail. \\ Une vie prometeue \\ et remarqué.
}

O poema vinha enquadrado por arabescos a bico-de-pena em cor de carvão, com desenhos florais em violeta, vermelho, azul, rosa, em flores, pétalas e botões. Mas a estória não se finda ou não quer se finar. Ela quer ser história e então pulsa no oco do desejo mais recôndito, sustentando a vida.

Anos mais tarde, manhã de um dia ensolarado, estando em Isla Negra, "templo sagrado" de Dom Pablo, eis que me deparo com uma explicação para a expressão "refém", resignificada no conjunto de carrancas que o poeta colecionou durante a vida hoje expostas no museu Pablo Neruda.

São máscaras femininas, algumas mostram seios desnudos, aludindo a variadas imagens figurativas, talhadas na proa de embarcações antigas e contemporâneas. São referidas a mulheres destinadas a "abrir os caminhos do destino" de barcos e barqueiros a enfrentarem perigos e perigos, reais ou imaginários, nos mares e rios do mundo.

"Les Ghislaine ne sont pas / des martyres / mais des figures de proue". Então, eu retornava a Santiago de Chile desde Viña Del Mar. Levara comigo um Neruda, "Los Versos del Capitán". Com ele atravessara a Cordillera, procedendo de Mendoza. Tanto me entusiasmara, a ponto de eu próprio ousar rabiscar com letra hesitante um poema autoral qao qual dei por título "Mascarón” (Carranca).

Esse seria o meu complemento para o que de lacunar restou no conto "Páramo" de João Guimarães Rosa...

Alguns modelos de carrancas 


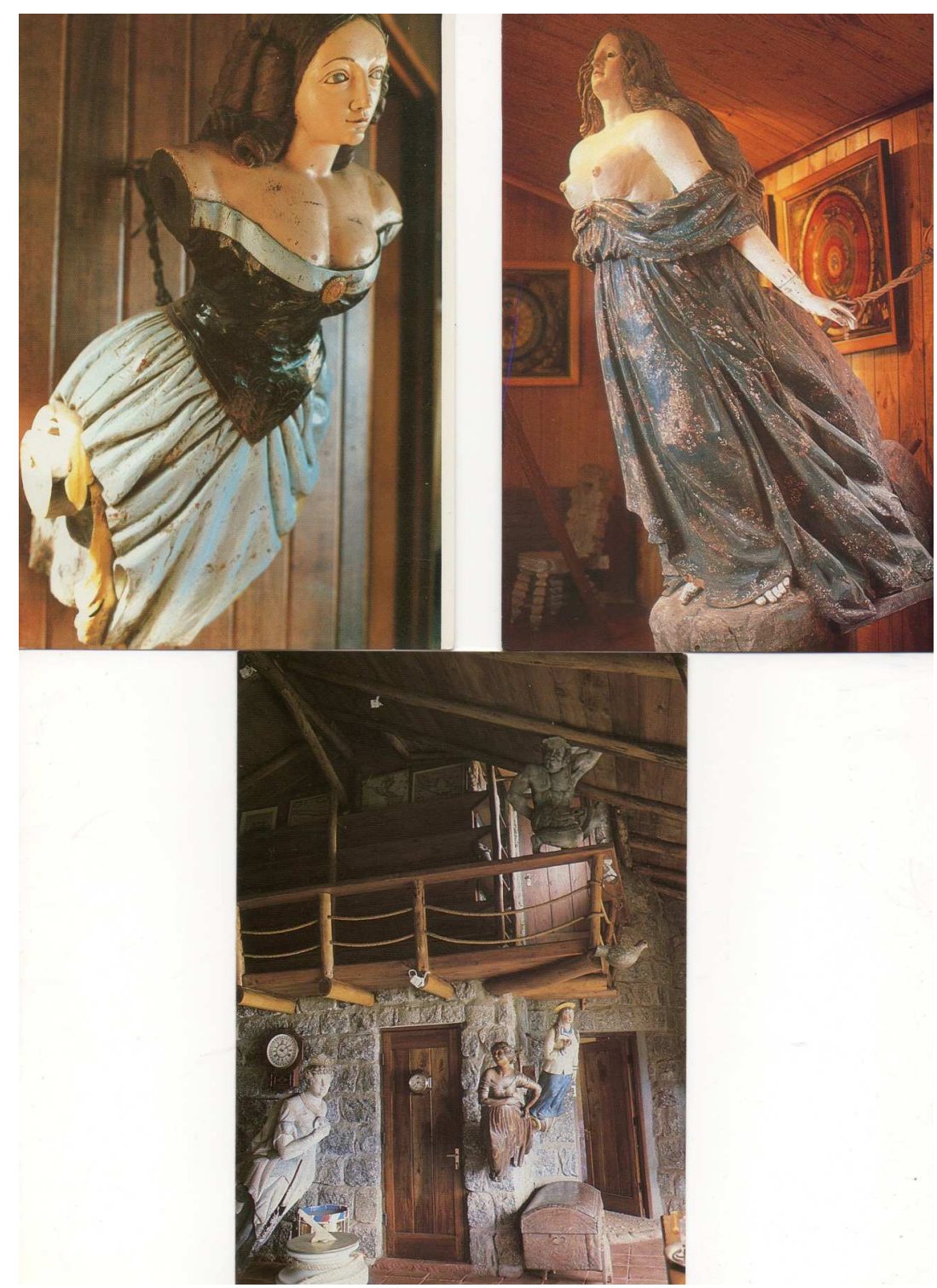

Da esquerda para direita: Fig. 1 Jenny Lind, Fig. 2 Guilhermina; ambas fotografias de Hilde Krassa; Fig.3 Living da Casa. Todas correspondem a cartões postais da Casa-Museo Isla Negra, Chile.

\section{Referências}

Almeida, Leonardo Vieira de (2011). Veredas do Grande Conto: a descoberta do sertão em Guimarães Rosa, Rio de Janeiro: Ed. PUC-RIO \& Uapê.

Andrade, Carlos Drummond de (2002). "A Máquina do Mundo". In Folha de São Paulo, Mais!, 27 out., p. 20.

Berlinck, Manoel Tosta (2012). "O Neutro". In Tempo psicanalítico, Rio de Janeiro, v. 44, n. 1, p. 183-199. 
Mimeo.

(2010). O Método Clínico: projeto temático de pesquisa, São Paulo, CNPq.

(2008a). "Anotações do curso sobre o Método Clínico". In III Congresso Internacional de Psicopatologia Fundamental e IX Congresso Brasileiro de Psicopatologia Fundamental, 04 a 07 de setembro, Niterói, RJ.

(2008b). Psicopatologia Fundamental, São Paulo: Escuta.

(Org.) (2005). Obsessiva Neurose, São Paulo: Escuta.

Bloch, Marc (2002). A Apologia da História ou O Ofício do Historiador, Rio de Janeiro: Zahar.

Buck-Morss, Susan (2000). Dreamworld and Catastrophe: The Passing of Mass Utopia in East and West, Cambridge: MIT.

Cadernos de Literatura Brasileira (2006), Rio de Janeiro: Instituto Moreira Salles, n. 20 e 21: João Guimarães Rosa.

Campos, Haroldo de (1970). "A linguagem do lauretê". In Metalinguagem, 2. ed., Petrópolis, RJ: Vozes, p. 47-53.

Canetti, Elias (1988). O outro processo (as cartas de Kafka a Félice), Rio de Janeiro: Espaço e Tempo.

Carpentier, Alejo (1987). A harpa e a sombra, Rio de Janeiro: Bertran do Brasil.

Cerqueira, Marcelo Neder (2012). História da Memória, Tradição Oral e Vídeo História: reflexões metodológicas, PPGH/ICHF-UFF, Niterói, 2012. Mimeo.

Cerqueira, Marcelo Neder \& Cerqueira Filho, Gisálio (2007). "Vulnerabilidade Psíquica e Poder: sobre Arthur Schnitzler". In Latin America Journal of Fundamental Psychopatology on line, n. 1-1/22, maio.

Cerqueira Filho, Gisálio (2011). "Amor \& Morte em Arthur Schnitzler". In Passagens Revista Internacional de História Política e Cultura Jurídica, Rio de Janeiro, v. 3, n.1, jan./abr., p. $142-164$.

(2009). O Afeto é Político. Tese de Concurso para Professor Titular de Teoria Política na UFF (ICHF), Niterói.

(2006). Ecos de Strindberg: Dor e Medo na Clínica em Extensão. In Psicologia Clínica, Rio de Janeiro: PUC-RIO, v.18, n.1, p. 123-135.

(2005). Autoritarismo Afetivo: a Prússia como sentimento. São Paulo: Escuta.

(2002a). Édipo e Excesso, Porto Alegre: Sérgio Fabris Editor. 
(2002b). "Freud, a cultura e a política". In Revista Pulsional de Psicanálise, São Paulo, ano XV, n. 155, março, p. 55-66.

(1982). A questão social no Brasil: crítica do discurso político, Rio de Janeiro: Civilização Brasileira.

Cerqueira Filho, Gisálio; Neder, Gizlene (2000). Emoção e Política, Porto Alegre: Sérgio Fabris Editor.

Cordovez-Moure, José Maria (1962). Reminiscencias de Santa Fé y Bogotá, Madrid: Aguillar.

Costa, Ana Luiza Martins (2006). "Veredas de Viator". In Cadernos de Literatura Brasileira, Rio de Janeiro: Instituto Moreira Salles, n. 20/21, p. 10-58.

Decol, René Daniel (2006). “Uma certa Aracy, um certo João”. In Revista GOL - Linhas Aéreas, Secção "Gente”, p. 71-74.

Didi-Huberman, Georges (2012). Imagens apesar de tudo, Lisboa: KKYM.

(2011). O que nós vemos, o que nos olha, Porto: Dafne Editora.

(2009). La imagen supeniviente, Madrid: Editorial Abada.

Drumond, Josina Nunes (2008). As Dobras do Sertão: palavra e imagem - O neobarroco em Grande Sertão Veredas, de Guimarães Rosa, e Imagens do Grande Sertão, de Arlindo Daibert, São Paulo: Annablume.

Freud, S. (1996). "O Inconsciente". In História do Movimento Psicanalítico, trad. Jayme Salomão, Rio de Janeiro: Imago. (Edição Standard Brasileira das Obras Psicológicas Completas de Sigmund Freud; v. 14).

(1987). Neurose transferência: uma síntese, Rio de Janeiro: Imago.

Galvão, Walnice Nogueira (2008). Mínima Mímica: ensaios sobre Guimãres Rosa, São Paulo: Companhia das Letras.

Ginzburg, Carlo (2006). Medo, Reverência e Terror: Reler Hobbes Hoje, Laboratório Cidade e Poder, Departamento de História, Universidade Federal Fluminense, Niterói. Tradução de Luiz Fernando Franco.

Letras.

(1990). Mitos, emblemas, sinais: morfologia e história, São Paulo: Companhia das

Heidegger, Martin (2003). A caminho da linguagem, Petrópolis, RJ: Vozes.

Neves, Wilson das; Pinheiro, Paulo e Cesar (1996). "O samba é o meu dom". In Toque de Prima, Rio de Janeiro: Velas. Faixa 12. 
Osório, Tomás Vargas (2008). Regreso de la muerte, Bucaramanga: Dirección Clutural.

Pereira, Maria Luiza Scher (2007). "O Exílio em "Paramo" de Guimarães Rosa: dilaceramento e superação. In Psicanálise \& Barroco - Revista de Psicanálise, v. 5, n. 1, p. 7-21.

Pérez-Ricón, Hector (2012). El Pathos Corporeo em la Obra Pictórica de Julio Galán. Conferência pronunciada no V Congresso Internacional de Psicopatologia Fundamental e XI Congresso Brasileiro de Psicopatologia Fundamental, 06 de setembro, Fortaleza.

(2010). "Literatura e Psiquiatria". In Revista Latinoamericana de Psicopatologia Fundamental, São Paulo, v. 13, n.3, p 391-394.

Quinet, Antonio (1995). Imagem Rainha (parte I), Escola Brasileira de Psicanálise, Rio de Janeiro: Sete Letras.

Reguera, Isidoro (2010). "Abby Warburg: Inventor del museo virtual". In El Pais, Babelia, Madrid, n. 962, 01 maio.

Rodrigues, Márcia Barros Ferreira (2008). Ethos e Pathos: Violência e Poder em Casa Grande \& Senzala, de Gilberto Freyre. Projeto de Pós-doc. - Universidade Federal Fluminense, Niterói.

Rosa, João Guimarães (2006). Grande Sertão: Veredas. Edição comemorativa. Rio de Janeiro: Nova Fronteira.

(2001a). "Páramo". In Estas Estórias. Rio de Janeiro: Nova Fronteira, p. 261-290.

(2001b). Tutaméia (terceiras estórias), Rio de Janeiro: Nova Fronteira.

Said, Edward (1993). A representação do Intelectual - Conferências Reith, São Paulo: Companhia das Letras.

Santiago, Silviano (2012a). "Preste atenção!" In O Estado de São Paulo, Sabático, 23 jun.

(2012b). "Soroche o mal das alturas", artigo instigante publicado. In O Estado de São Paulo, Suplemento Sabático, 21 jul., p.2.

Schollhammer, Karl Erich (2012). "A sobrevivência de Aby Warburg". In O Globo, Caderno Prosa e Verso, Rio de Janeiro, 08 set., p. 5.

Schorske, Carl (1989). Viena fin de siècle: política e cultura, São Paulo: Companhia das Letras.

Sobral, Luis Felipe (2012). "No rastro de Piero". In Revista Brasileira de Ciências Sociais RBCS, São Paulo, v. 27, n. 79, p. 217-220.

Taboada Terán, Nestor (1977). Manchay Puytu: El amor que quiso ocultar a Dios, Buenos Ayres: Editorial Sudamericana. 
Tadié, Jean-Yves (2012). Le lac inconnu - entre Proust e Freud, Paris: Gallimard.

Torres Fierro, Danúbio (2012). "Romance entre o arcaico e o moderno". In O Estado de São Paulo, Suplemento Sabático, 18 ago., p. 6-7.

Vargas Osório, Tomás (1983). Regreso de la muerte, Bogotá: Concultura.

Vélez Escalón, Bairon Oswaldo (2012). "Intrusões: Guimarães Rosa-Bogotá: notas para uma tradução de Páramo". In Revista Tussaji, v. 1, p. 58-73.

. (2011). "Páramo", tradução do texto de João Guimarães Rosa. In Revista Número 69, p. 20-33.

Warburg, Aby (2012). O nascimento de Vênus e a A Primavera de Sandro Botticelli, (1891), tradução para o português de A. Mourão, Lisboa: KKYM.

Zischler, Hanns (2005). Kafka vai ao cinema, Rio de Janeiro: JZE.

Zizek, Slavoj (2012). Less Than Nothing:Hegel and The Shadow os Dialetic Materialism, London: Verso.

(2010). Living in The End Time, London: Verso.

(2002). The Frágil Absolute, London: Verso.

Recebido para publicação em dezembro de 2012.

Aprovado para publicação em fevereiro de 2013. 